\title{
Additive biomass models for Quercus spp. single-trees sensitive to temperature and precipitation in Eurasia
}

\author{
Vladimir A. Usoltsev ${ }^{1,2}$, Walery Zukow ${ }^{3 *}$, Anna A. Osmirko ${ }^{1}$, Ivan S. Tsepordey ${ }^{2}$, \\ Viktor P. Chasovskikh ${ }^{1}$ \\ ${ }^{1}$ Ural State Forest Engineering University Sibirskii trakt 37, Yekaterinburg, \\ 620100 Russian Federation \\ ${ }^{2}$ Botanical Garden, Russian Academy of Sciences, Ural Branch, 8 Marta 202a, \\ Yekaterinburg, 620144 Russian Federation \\ ${ }^{3}$ Department of Spatial Management and Tourism, Faculty of Earth Sciences, \\ Nicolaus Copernicus University, Lwowska 1, 87-100 Toruń, Poland, \\ *e-mail: w.zukow@wp.pl
}

Received: 27 June 2019 / Accepted: 11 July 2019

\begin{abstract}
The analysis of the biomass of oak (genus Quercus spp.) trees on the aboveground component composition based on regression equations having the additive biomass structure is fulfilled. Two trends of changes in the tree biomass structure are revealed: due to the mean January temperature and due to the mean annual precipitation. It was shown for the first time that both trends are mutually determined: the intensity of biomass trend in relation to the temperature is changing when depending on the level of precipitation, and the intensity of biomass trend in relation to precipitation level is changing during to a transition from the cold zone to the warm one and vice versa.
\end{abstract}

Key words: oak trees, tree biomass, allometric models, additive biomass equations, mean January temperature, mean annual precipitation.

\section{Introduction}

Information about forest tree biomass can easily be derived through allometric equations, as it is done for example for biomass stock per ha, especially in many-species forests (Dahlberg et al., 2004; Zeng et al., 2018; Usoltsev et al., 2019a), for greenhouse gas reporting (de Miguel et al., 2014), for analysis of national forest inventories data, in ecological studies (Marklund, 1987; Riedel \& Kändler, 2017), as well as in gas-exchange, nutrient and energy flow studying, forest growth and biomass allocation models (Zianis et al., 2005; Vonderach et al., 2018).
All above mentioned equations are usually internally contradictory, they are not harmonized by the biomass structure, i.e. they do not provide the additivity of component composition, according to which the total biomass of components (stems, branches, needles, roots) obtained by "component" equations would be equal to the value of biomass obtained by the total biomass equation (Kozak, 1970). The additivity methods can be divided into aggregative (Parresol, 2001) and disaggregative (Dong et al., 2015) approaches. It was recently showed that having in mind the result correctness, both approaches differ only slightly (Affleck \& Diéguez-Aranda, 2016). The development 
of regional allometric models of tree biomass sensitive to climate variables has shown both negative (Forrester et al., 2017) and positive (Zeng et al., 2017) results. The influence of climatic changes on the biomass of a particular tree species in the format of additive models according to transcontinental hydrothermal gradients was not been studied, with some single exceptions (Usoltsev et al., 2019a, b).

In the present study, the first attempt is made to simulate the changes in the additive component composition of tree aboveground biomass in oak forests on Trans-Eurasian hydrothermal gradients. In the simulation we used the database of the biomass of 530 sample trees (genus Quercus spp.), the distribution of sample plots of which in the territory of Eurasia is shown in Figure 1 (Usoltsev, 2016; Lakida et al., 2017).

\section{Materials and methods}

Of the above-mentioned two databases (Usoltsev, 2016; Lakida et al., 2017) containing data on biomass and dendrometric parameters, 530 trees were selected for the analysis, including 8 species-vicariants of the genus Quercus spp. Their distribution by regions, tree species and mensuration indices is presented in Table 1.

Each sample plot on which tree biomass estimating was performed is positioned relatively to the isolines of the mean January temperature (Fig. 2) and relatively to the isolines of mean annual precipitation (Fig. 3). The matrix of harvest data was compiled, in which the biomass component values and mensuration tree parameters were related with the corresponding values of mean January temperature and precipitation, then included in the regression analysis procedure.

It is known that a stem diameter is a main predictor that most explains the variation of tree biomass, and their relationship as the most common and biologically determined is described by the allometric function. Allometry determines how tree shape and function scale with each other, related through size. Allometric relationships help scale processes from the individual to the global scale and constitute a core component of vegetation models. Allometric relationships have been expected to emerge from optimization theory, yet they do not suitably predict empirical data (Fischer et al., 2019). On the allometry basis, several theories are proposed: the pipe model (Huber, 1925, 1927; Shinozaki et al., 1964a, b), the functional equilibrium model (Davidson, 1969), the fractal model (West et al., 1999), the metabolic scaling theory (when scaling exponent is constant) (West et al., 1997), the theory of adaptive mass distribution (when scaling exponent changes dynamically with size) (Poorter et al., 2015) and some of their modifications (Enquist \& Niklas, 2001, 2002). However, when calculating allometric models of tree biomass there is always a residual variance, reflecting, in particular, the discrepancy between the annual dynamics of the crown

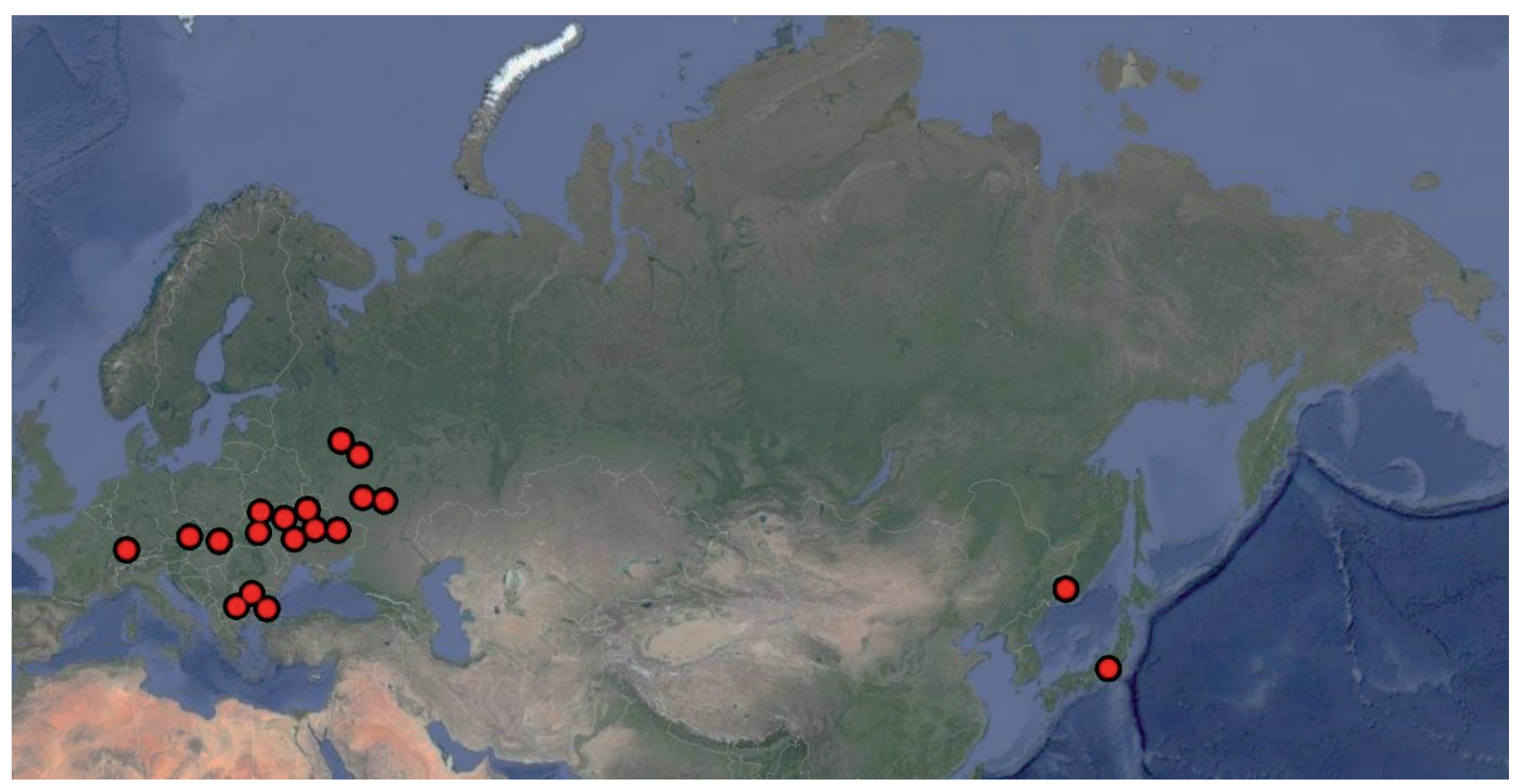

Figure 1. Distribution of sample plots with biomass measurements $(\mathrm{kg})$ of 530 oak sample trees on the territory of Eurasia 
Table 1. Distribution of the 530 oak sample trees by countries, regions, tree species and mensuration indices

\begin{tabular}{|c|c|c|c|c|}
\hline \multirow{2}{*}{ Regions } & \multirow{2}{*}{$\begin{array}{c}\text { Species of the } \\
\text { genus Quercus spp. }\end{array}$} & \multicolumn{2}{|c|}{ Ranges: } & \multirow{2}{*}{$\begin{array}{c}\text { Data } \\
\text { number }\end{array}$} \\
\hline & & age, years & diameter, cm & \\
\hline Czech Republic, Switzerland & Q. robur $\mathrm{L}$. & $13 \div 104$ & $4.0 \div 69.7$ & 16 \\
\hline Bulgaria & $\begin{array}{l}\text { Q. rubra L., } \\
\text { Q. robur subsp. pedunculiflora } \\
\text { (K.Koch) Menitsky, } \\
\text { Q. petraea (Mat.) Liebl., } \\
\text { Q. frainetto Ten. }\end{array}$ & $17 \div 70$ & $1.5 \div 29.5$ & 49 \\
\hline Hungary & Q. petraea (Mat.) Liebl. & 68 & $15.8 \div 23.8$ & 9 \\
\hline The Ukraine & Q. robur $\mathrm{L}$. & $6 \div 128$ & $2.5 \div 50.5$ & 370 \\
\hline European part of Russia & Q. robur $\mathrm{L}$. & $12 \div 130$ & $1.1 \div 46.9$ & 66 \\
\hline Russian Far East & Q. mongolica Fisch. ex Ledeb. & $56 \div 166$ & $9.5 \div 34.5$ & 7 \\
\hline Japan & $\begin{array}{l}\text { Q. serrata Murray, } \\
\text { Q. mongolica Fisch. ex Ledeb. }\end{array}$ & $4 \div 40$ & $1.1 \div 16.5$ & 13 \\
\hline
\end{tabular}

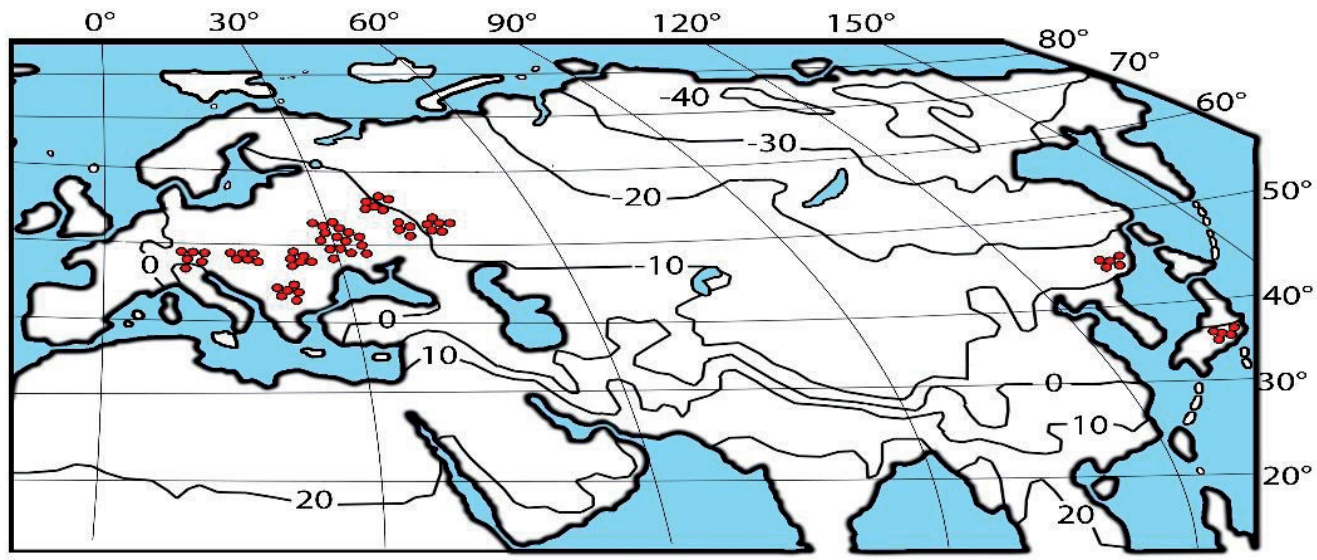

Figure 2. Distribution of biomass harvest data of 530 oak sample trees on the map of the mean January temperature, ${ }^{\circ} \mathrm{C}$ (World Weather Maps, 2007)

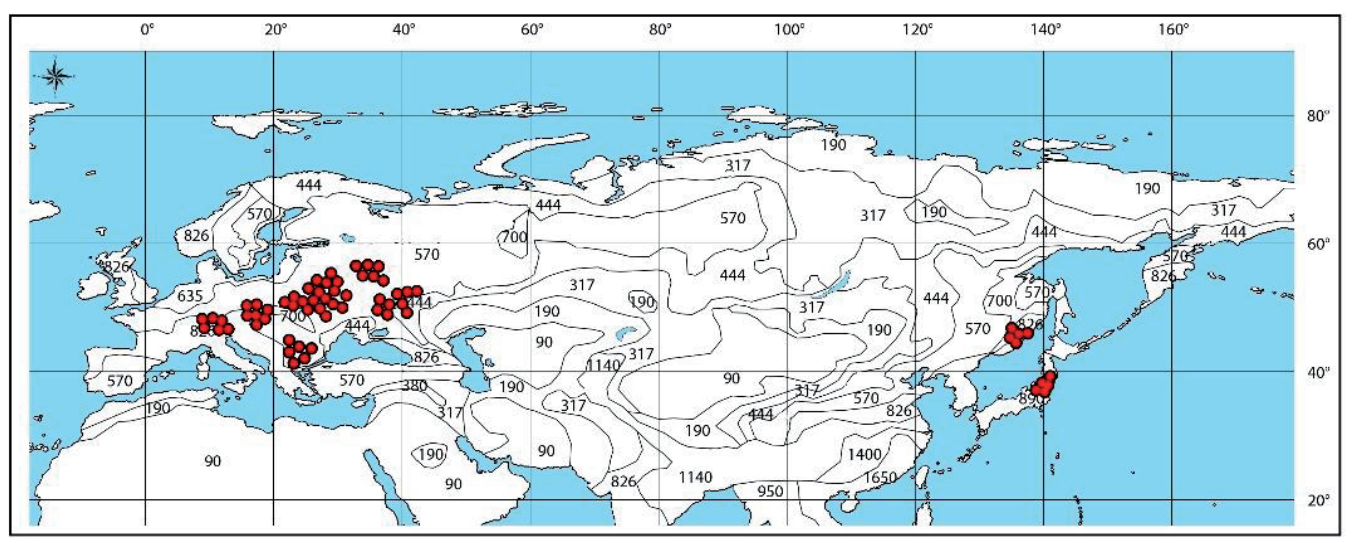

Figure 3. Distribution of biomass harvest data of 530 oak sample trees on the map of the mean annual precipitation, mm (World Weather Maps, 2007) 
mass, especially of the foliage, and the relative conservatism of a stem diameter, as an accumulator of its annual increments (Usoltsev, 1988), as well as differences of age status, soil and climatic conditions.

Total tree height is not always available in field measurements, and it may sometimes be better not to involve it in biomass estimation procedure (Williams \& Schreuder, 2000). In this study, the task is to extract the climatic component from the residual dispersion of a model obtained during to calculation of tree biomass by stem diameter. To the share of climatic factors was predominant in this "information noise", it is necessary to take into account in the model in addition to the diameter, also the tree age, which is a factor largely determining the structure of tree biomass (Nikitin, 1965).

A negative relationship between the crown biomass of equal-sized trees and their age in forest stands is well known. Thus, the crown mass of the tree with a diameter of $12 \mathrm{~cm}$ at the age of 15 years exceeds that at the age of 35 years at the birch by 1.5-2.0 times, and at the aspen by 2.4-4.4 times (Usoltsev, 1972) due to the age shift of the cenotic position of equal-sized trees: at the age of 15 years such tree is the leader, and at the age of 35 years it is the depressed tree, a candidate for dying. The influence of age on stem biomass in comparison with other components is minimal due to the relative stability of the stem shape: with the same stem shape and the corresponding volume, its biomass changes with age mainly due to age-related changes in the basic density related to a decrease in the proportion of sapwood having a reduced dry matter content compared to the heartwood (Usoltsev, 1988). Tree age, all other conditions being equal, also affects the mass of roots in terms of root-shoot relationships (Kazaryan, 1969).

We have in our database only 47 trees having both aboveground biomass and root one, represented by Central Europe, European part of Russia and Japan. Because of small root experimental data, we do not involve the bio- mass of roots into our additive biomass system. Root biomass data are high labour-consuming, and therefore they determined by researchers not at all sample plots, often without specifying the method of their estimation. The analysis of the world data of underground tree biomass has showed that due to the imperfection of methods to estimate fine root biomass, the total underground biomass of trees and stands may be underestimated two to five times (Usoltsev, 2018).

We limited ourselves to the calculation of the coefficient of determination and the standard error. We have not calculated additional characteristics of the equation adequacy, such as the mean prediction error, the relative mean prediction error, the mean absolute error, and the relative mean absolute error, since they all are derived from the determination coefficient.

The disaggregation method of two-step proportional weighing, based on the principle "from general to particular" is developed as an alternative to the independent (without additivity) fitting approach. It has been implemented in two versions: as a sequential (Zheng et al., 2015) and parallel (Zhang et al., 2016) disaggregating additive systems of equations for aboveground biomass (Fig. 4). According to the structure of the disaggregation model of a two-step additive equation system (Zheng et al., 2015), the aboveground biomass $P_{a}$, estimated by an initial equation, is divided into biomass components by means of proportional weighting the corresponding component initial equations (see: Dong et al., 2015; Usoltsev et al., 2019a, b).

The coefficients of the regression equations of all two steps are evaluated simultaneously, that ensures the additivity of the biomass of all components (Dong et al., 2015). Since the regression coefficients in the designed model were calculated on the log-transformed data, a corresponding correction is introduced in the equations to eliminate the displacements caused by the logarithmic transformation of the variables (Baskerville, 1972).

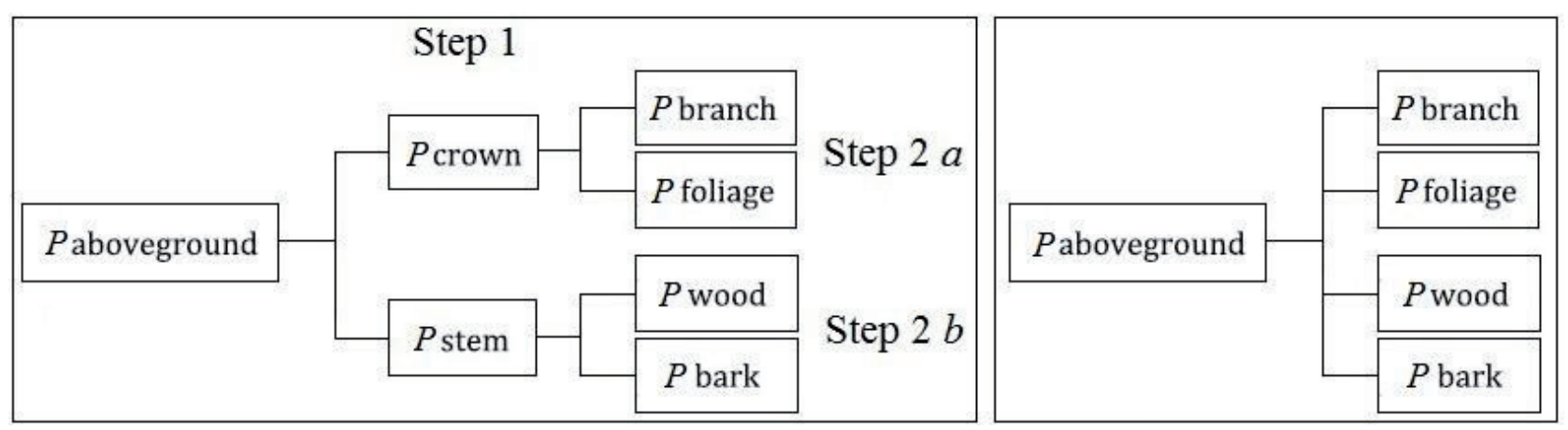

Figure 4. The pattern of the disaggregating two-step proportional weighting additive model of sequential (left) and parallel (right) schemes. The schemes show relationship between each biomass component, where lines from left to right indicate disaggregation and from right to left indicate summation (Zheng et al., 2015; Zhang et al., 2016) 
We adhered to the concept that there is only one definite variant of stand (and tree) biomass structure corresponding to a given structure of taxonometric parameters (morphological structure) of a tree stand, determined by local forest growth conditions (Usoltsev, 2007). If in some region we find a forest stand of the same morphological structure, then the structure of its biomass is likely to be the same, provided there were no anthropogenous and other abiotic influences. But as the range of expansion of woody species (genus), this compliance will be increasingly violated as a result of increasing the diversity of forest growth conditions. This change in the diversity of forest environment has geographical causes and in the regression multiple model is expressed by an increase in residual dispersion ("information noise"). In terms of biogeography, the increase of variability of this residual variance as a consequence of increasing diversity of forest environment, is most likely due to climate variables, such as temperature and precipitation, which are included in our models as additional independent variables.

\section{Results}

Based on the above, the following structure of the regression model is suggested:

$$
\begin{gathered}
\ln P_{i}=a_{0 i}+a_{1 i}(\ln A)+a_{2 i}(\ln D)+a_{3 i}(\ln D)^{2}+ \\
+a_{4 i}[\ln (T+20)]+a_{5 i}(\ln P R)+a_{6 i}[\ln (T+20)](\ln P R)
\end{gathered}
$$

where $P_{i}$ is biomass in dry condition of $i$-th component, $\mathrm{kg} ; A$ is tree age, yrs; $D$ is stem diameter at breast height, $\mathrm{cm} ; i$ is the index of biomass component: above- ground $(a)$, crown $(c)$, foliage $(f)$, branches $(b)$, stem above bark $(s)$, stem wood $(w)$ and stem bark $(b k) ; T$ is mean January temperature, ${ }^{\circ} \mathrm{C} ; P R$ is mean annual precipitation, $\mathrm{mm}$.

According to the theory of adaptive mass distribution, the scaling exponent (or exponent at the stem diameter in the allometric model) is not a constant, and in log-log coordinates the relationship has the nonlinear form (Poorter et al., 2015). To account for this nonlinearity, the stem diameter in the model (1) is introduced in the form of a second-order logarithmic polynomial:

$$
\ln P_{i}=f\left[(\ln D),(\ln D)^{2}\right]
$$

Since the mean January temperature in the northern part of Eurasia has negative values, the corresponding independent variable is modified to the form $(T+20)$ to be subjected to logarithmic procedure. The schematic map of the isolines of mean January temperature, rather than the mean annual temperature, is used, since climate warming is most pronounced in the cold half of the year (Golubyatnikov \& Denisenko, 2009; Laing \& Binyamin, 2013; Felton et al., 2016). In this regard, a similar parallel trend of another level is interesting: according to the report of National Oceanic and Atmospheric Administration (2017), warming in the Arctic is twice as fast as in other parts of the Earth, and "the Arctic is on the front lines of climate change" (https://www.noaa.gov/explainers/ changing-arctic-greener-warmer-and-increasingly-accessible-region) (Blunden et al., 2018).

Characteristic of equations (1) is obtained by regression analysis, and after correcting on logarithmic transformation by Baskerville (1972) and anti-log transforming

\begin{tabular}{|c|c|c|c|c|c|c|c|c|c|}
\hline 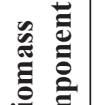 & \multicolumn{7}{|c|}{ Regression coefficients of the model } & \multirow{2}{*}{\begin{tabular}{|l}
$\operatorname{adjR}^{2 *}$ \\
0.989
\end{tabular}} & \multirow{2}{*}{$\begin{array}{l}S E^{*} \\
1.22\end{array}$} \\
\hline$P_{a}$ & 3.49E-09 & $A^{0.1098}$ & $D^{1.9591}$ & $D^{0.0823(\ln D)}$ & $(T+20)^{5.6803}$ & $P R^{2.6737}$ & $(T+20)^{-0.8555(\ln P R)}$ & & \\
\hline$P_{c}$ & $2.10 \mathrm{E}-11$ & $A^{-0.3144}$ & $D^{1.7957}$ & $D^{0.1310(\ln D)}$ & $(T+20)^{6.5197}$ & $P R^{3.5835}$ & $(T+20)^{-1.0249(\ln P R)}$ & 0.911 & 1.71 \\
\hline$P_{s}$ & $3.32 \mathrm{E}-08$ & $A^{0.2115}$ & $D^{1.9960}$ & $D^{0.0733(\ln D)}$ & $(T+20)^{4.8111}$ & $P R^{2.2139}$ & $(T+20)^{-0.7165(\ln P R)}$ & 0.987 & 1.25 \\
\hline$P_{f}$ & $9.41 \mathrm{E}-07$ & $A^{-0.5925}$ & $D^{1.6748}$ & $D^{0.0862(\ln D)}$ & $(T+20)^{4.3379}$ & $P R^{1.8895}$ & $(T+20)^{-0.6925(\ln P R)}$ & 0.871 & 1.67 \\
\hline$P_{b}$ & $3.47 \mathrm{E}-13$ & $A^{-0.1857}$ & $D^{2.0212}$ & $D^{0.0966(\ln D)}$ & $(T+20)^{6.9935}$ & $P R^{4.0371}$ & $(T+20)^{-1.0841(\ln P R)}$ & 0.901 & 1.84 \\
\hline$P_{w}$ & 4.00E-08 & $A^{0.3001}$ & $D^{2.2722}$ & $D^{0.01875(\ln D)}$ & $(T+20)^{4.4532}$ & $P R^{2.0392}$ & $(T+20)^{-0.6545(\ln P R)}$ & 0.984 & 1.28 \\
\hline$P_{b k}$ & $2.17 \mathrm{E}-13$ & $A^{0.1331}$ & $D^{1.3506}$ & $D^{0.1655(\ln D)}$ & $(T+20)^{8.7348}$ & $P R^{3.9457}$ & $(T+20)^{-1.3086(\ln P R)}$ & 0.960 & 1.40 \\
\hline
\end{tabular}
is given in Table 2.

Table 2. Characteristics of equations (1)

* adj $R^{2}$ - coefficient of determination adjusted for the number of parameters; $S E$ - equation standard error. 
All regression coefficients of equations (1) are characterized by the Student's significance level of 0.05 and better [including at variables $(\ln D)$ and $\left.(\ln D)^{2}\right]$, and the resulting equations are adequate to the original values presented in the available database. Unlike of our previous result on larch tree biomass (Usoltsev et al., 2019a), where the combined effect of temperature and precipitation was not statistically significant (Student's test $t_{a k t}$ is from 0.08 to 1.33 , which is below the standard value $t_{05}=1.96$ ), this model includes synergism $[\ln (T+20)](\ln P R)$, which is significant $\left(t_{a k t}\right.$ is from 2.04 to 6.49 , which is higher than the standard value $\left.t_{05}=1.96\right)$ for all biomass components. When using a 3D-interpretation, this means a "propellershaped" surface of biomass in dependence upon temperature and precipitation, which was previously confirmed by the example of tree biomass of two-needled pines (Usoltsev et al., 2019b).

The designed initial equations (1) are then modified to the additive form according to the early published algorithm (see: Dong et al., 2015; Usoltsev et al., 2019a, b), structure of which is shown in Figure 4 (left), and the final form of the transcontinental additive model of the component composition of oak tree biomass is shown in Table 3 .

Next, it is necessary to find out whether the additive model obtained is enough adequate and how its characteristics relate to the adequacy of initial equations. To do this, the first and the second models are tabulated on the empirical measurement data and the calculated values of biomass are compared with the empirical ones using the coefficient of determination. The comparison results shown in Figure 5 , indicate that the adequacy of the two systems of equations are close to each other.
Due to the high complexity of obtaining the age of trees in comparison with the stem diameter measuring, one use specially designed equation or table that reflects the relationship of the tree age with the stem diameter. To this end, the equation ( 3 ) is calculated:

$$
\begin{gathered}
A=\exp \{-1.6598+0.6774(\ln D)+ \\
+2.2621[\ln (T+20)]+0.9003(\ln P R)-0.4865[\ln (T+20)] \\
(\ln P R)\} ; \operatorname{adj} R^{2}=0.747 ; S E=1.42
\end{gathered}
$$

Using the result of tabulating eq. (1) by the given values $A, D, T$ and $P R, 3 \mathrm{D}$-dependences of biomass components on temperature $T$ and precipitation $P R$ for trees aged 100 years with $D=24 \mathrm{~cm}$ and $\mathrm{H}=22 \mathrm{~m}$ were designed (Fig. 6).

To estimate climate-related changes in the total biological productivity of oak stands, the above equations, calculated only for aboveground tree biomass, are not sufficient. Because of the small experimental data of root biomass, we calculated the roots-to-shoot ratio in dependence upon the defining variables, having in mind the available 47 data. Of the morphology-caused variables, only age is statistically significant, and the following equation is obtained

$$
\begin{gathered}
P_{r} / P_{a}=\exp \{-21.6606-0.8536(\ln A)-2.7020[\ln (T+20)]+ \\
\quad+4.7564(\ln P R)\} \\
\text { adj } R^{2}=0.856 ; S E=1.20
\end{gathered}
$$

where $P_{r}$ is tree root biomass, $\mathrm{kg}$. Equation (4) may be used in a rough estimation of underground biomass on tree and forest levels.

Table 3. Final three-step additive model of oak tree biomass

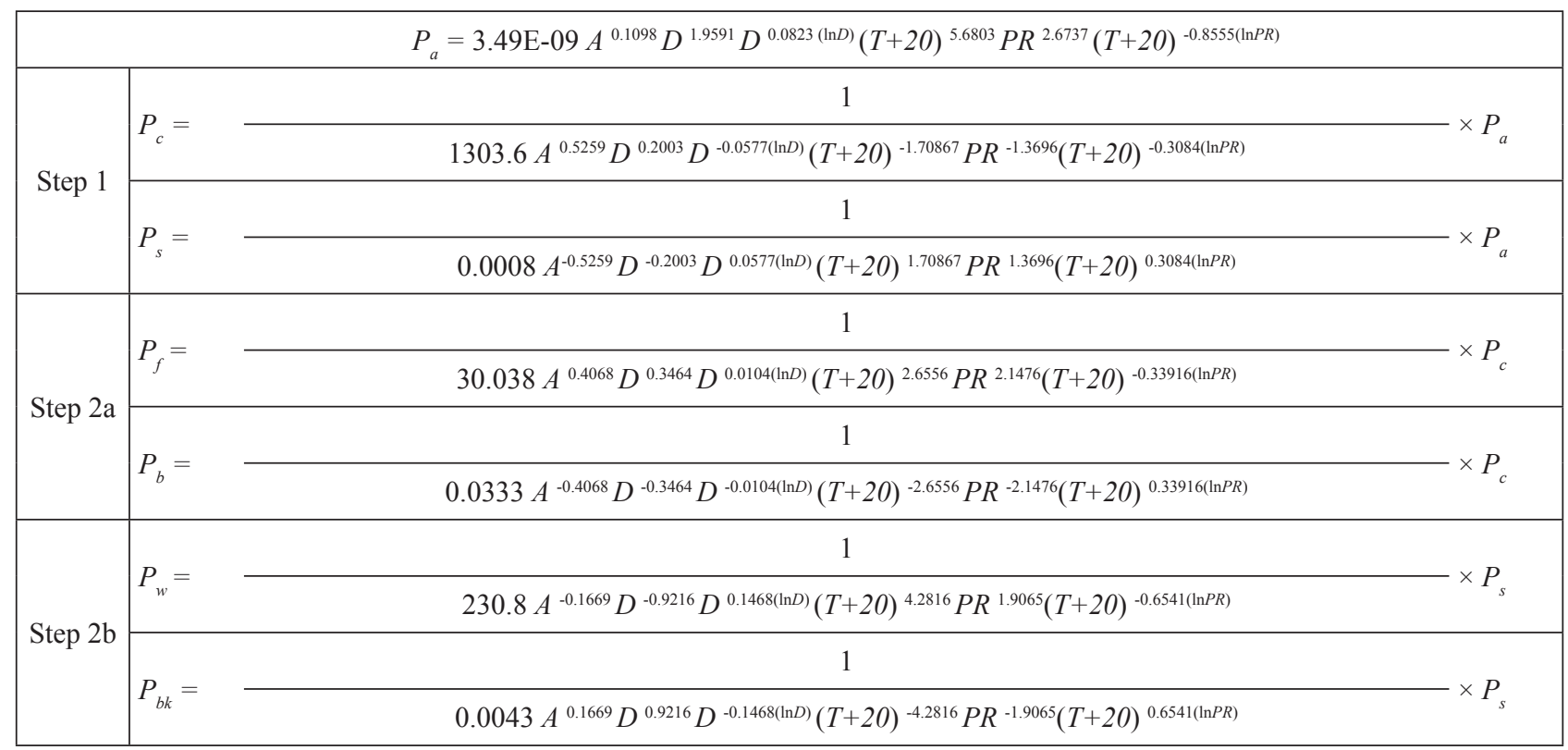




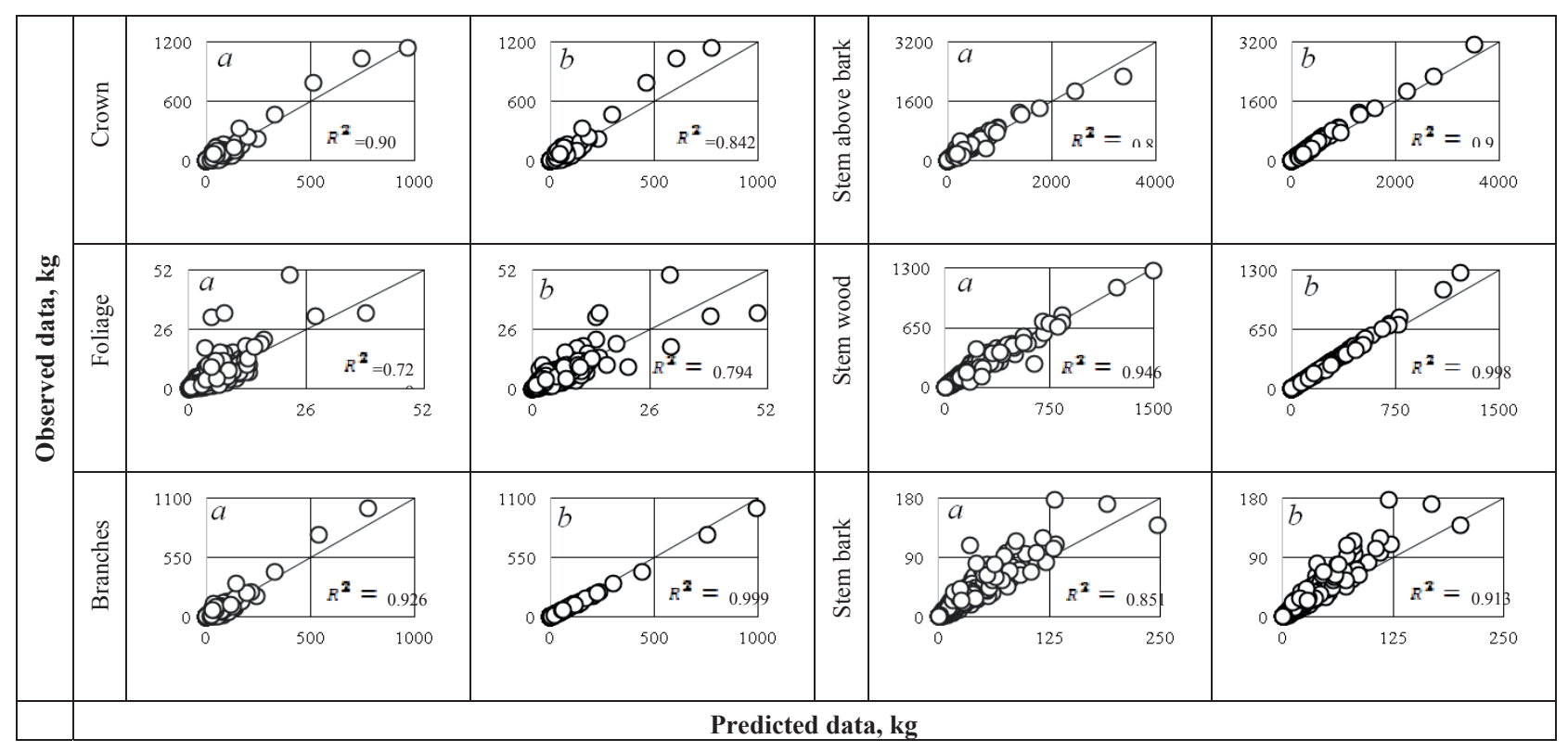

Figure 5. The ratio of the harvest biomass and its values obtained by calculating the initial $(a)$ and additive $(b)$ models of the oak tree biomass

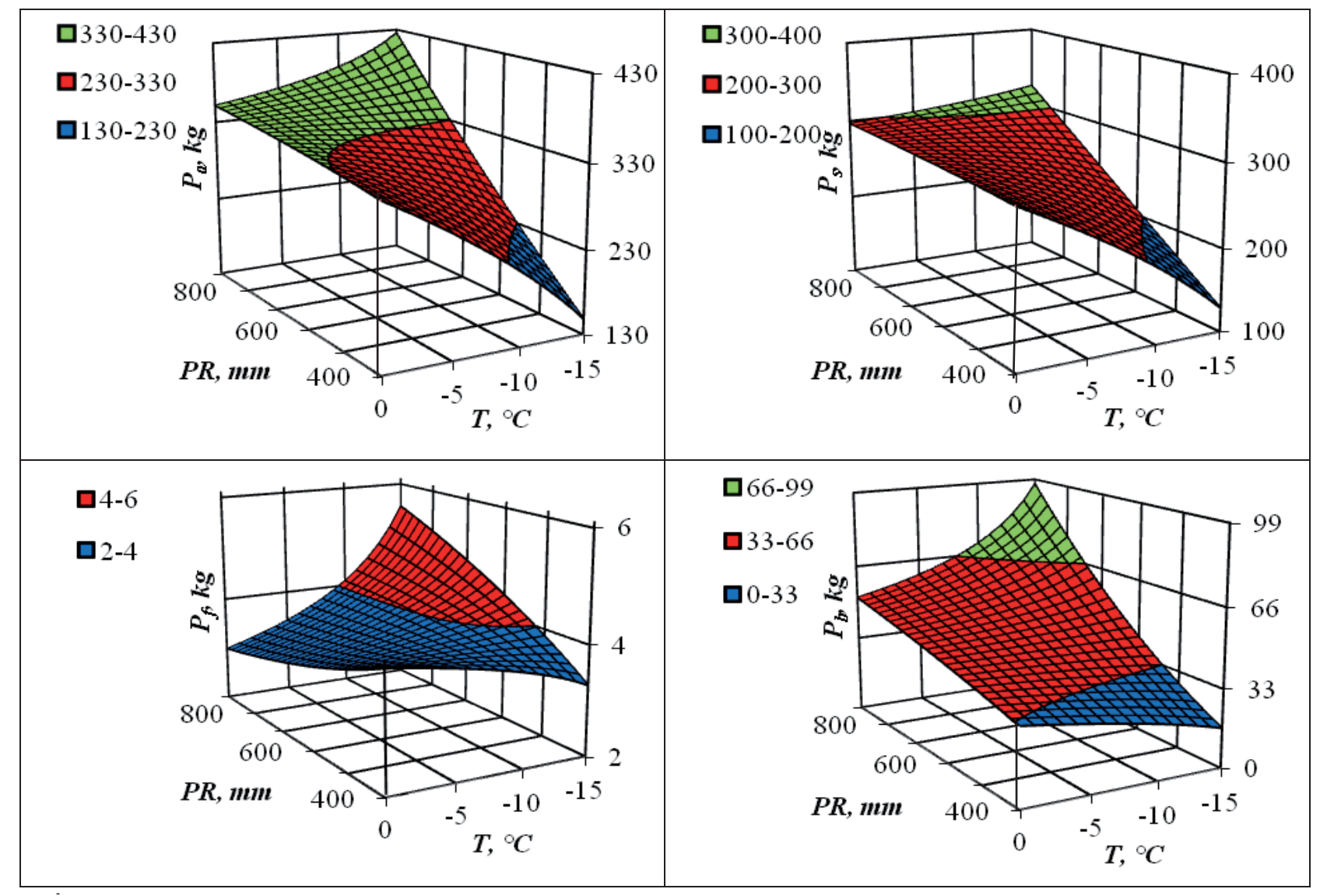

Figure 6. Dependence of oak tree biomass upon the January mean temperature $(T)$ and precipitation $(P R)$. Designations: $P_{a}, P_{s}, P_{\rho}$ and $P_{b}$ are correspondingly biomass: aboveground, stems, foliage, and branches, $\mathrm{kg}$ 
The obtained models of oak tree biomass make them possible to establish quantitative changes in the structure of tree biomass due to climatic changes, in particular, the mean temperature of January and mean annual precipitation. The percentage change in the structure of biomass is associated with the ratio of these two climatic variables.

In Figure 7 it is shown the change in the tree biomass $(\Delta, \%)$ with an increase in temperature by $1^{\circ} \mathrm{C}$ in different ecoregions, characterized by different values of temperature and precipitation. It is assumed that climate change does not affect precipitation, which changes only geographically (by regions), and the temperature as a result of the expected climate change increases by $1^{\circ} \mathrm{C}$ at different territorial (zonal) temperature levels, designated as $-15 \Delta \ldots 0 \Delta$. Figure 7 shows the general pattern of increase of all the biomass components in moderate dry areas $(\mathrm{PR}=400 \mathrm{~mm})$ and decrease in water-rich areas $(\mathrm{PR}=$ $700-900 \mathrm{~mm}$ ) with an increase in temperature by $1^{\circ} \mathrm{C}$ in all temperature zones of Eurasia.

In Figure 8 it is shown the change of tree biomass $(\Delta, \%)$ with the increase in precipitation by $100 \mathrm{~mm}$ in areas characterized by different values of temperature and precipitation. It is assumed that the January temperature changes only geographically, and precipitation as a result of the expected climate change increases by $100 \mathrm{~mm}$ at different territorial levels of precipitation, designated as $400 \Delta \ldots 900 \Delta$. Figure 8 shows the common pattern of increase of the all biomass components with an increase in annual precipitation by $100 \mathrm{~mm}$ in all temperature zones of Eurasia and in all regions that differ in precipitation, with exception of foliage biomass that is decreasing in the regions of warm and moderate temperatures (from $0^{\circ} \mathrm{C}$ to $\left.-1^{\circ} \mathrm{C}\right)$.

\section{Discussion}

Analysis of the 3D-surfaces in Figure 6 allows us to draw some nontrivial conclusions. As we can see there, all of the biomass components vary according to approximately one overall scheme, but in different proportions. The dependence, common to all of the components: in cold climatic zones $\left(T=-15^{\circ} \mathrm{C}\right)$, any increase in rainfall leads to corresponding increase in the biomass value, and in moder-

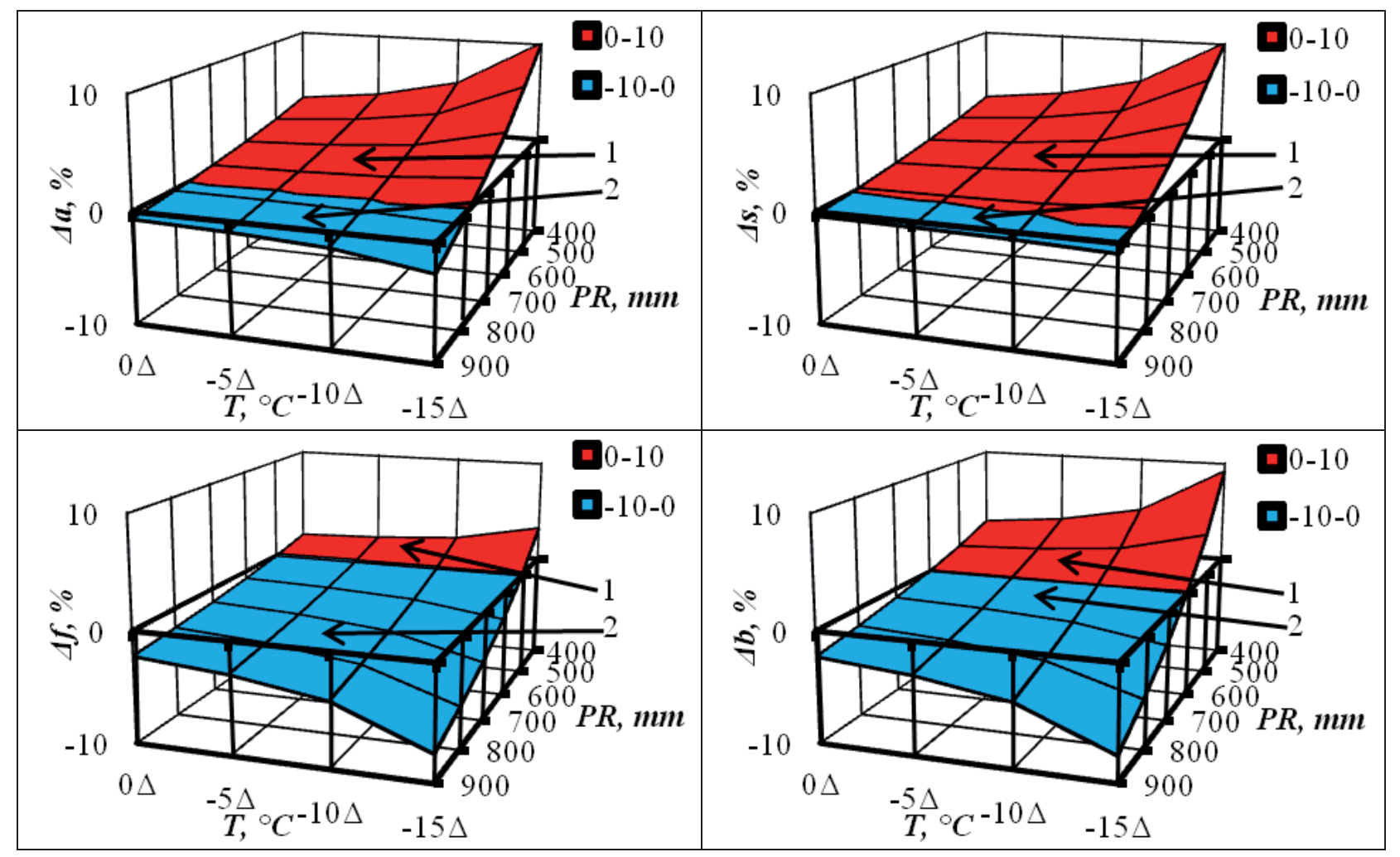

Figure 7. Change of tree biomass with $(+)$ (surface 1) and (-) (surface 2) when temperature increasing by $1{ }^{\circ} \mathrm{C}$ due to the expected climate change at different territorial levels of temperature and precipitation. Symbols $\Delta_{a^{\prime}} \Delta_{s}, \Delta_{f}$ and $\Delta_{b}$ on the ordinate axes mean the change $( \pm \%)$ of biomass of aboveground, stems, foliage and branches, respectively, with the temperature increase by $1^{\circ} \mathrm{C}$ and at the constant precipitation 


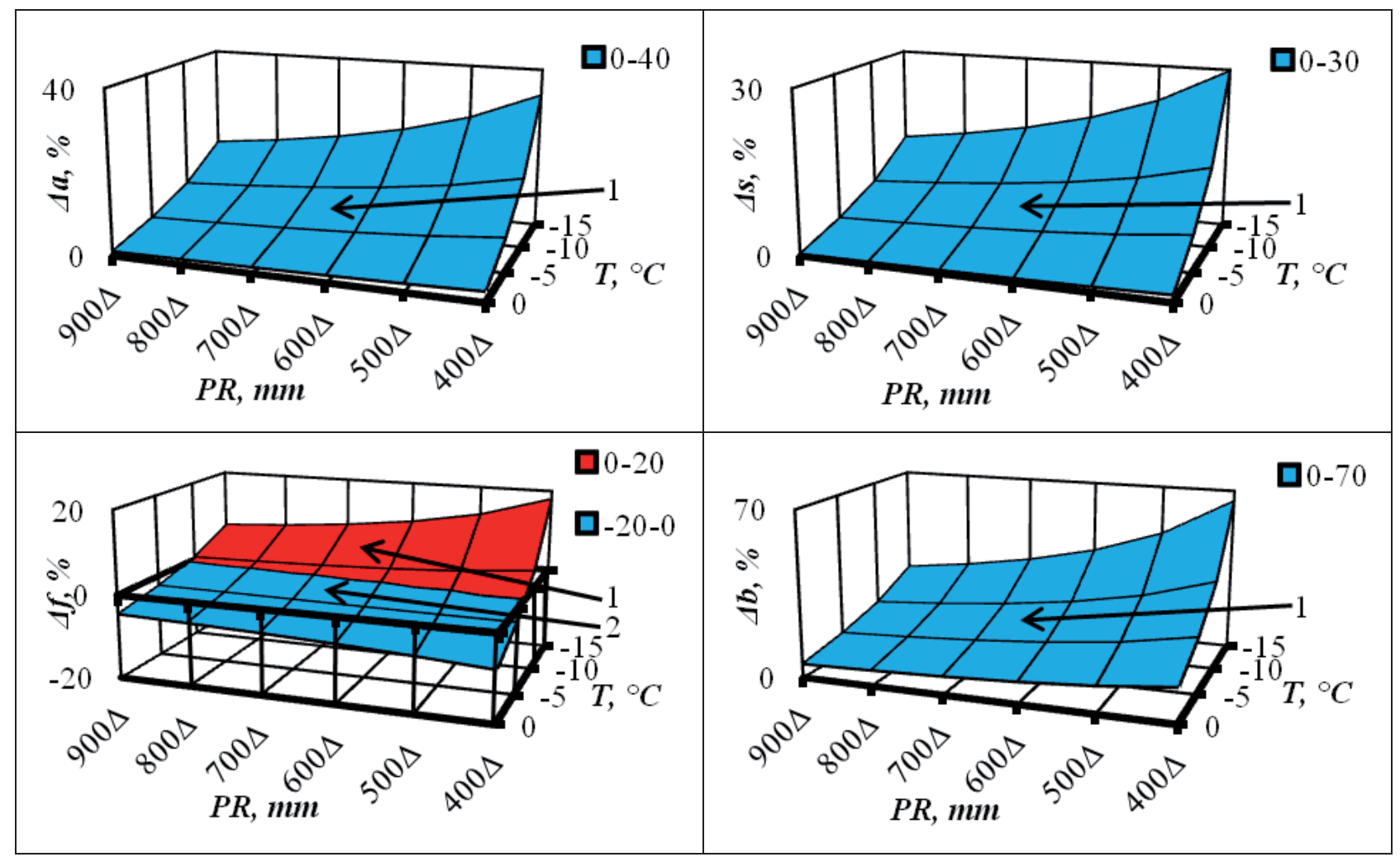

Figure 8. Change of tree biomass with (+) (surface 1) and (-) (surface 2) when precipitation increasing by $100 \mathrm{~mm}$ due to the expected climate change at different territorial levels of temperature and precipitation. The symbols $\Delta \mathrm{a}, \Delta \mathrm{s}, \Delta \mathrm{f}$ and $\Delta \mathrm{b}$ along the ordinate axes represent the change $( \pm \%)$ of aboveground, stems, needles and branches biomass, respectively, with precipitation increase by $100 \mathrm{~mm}$ and at the constant mean temperatures of January

ate warm zones $\left(T=0^{\circ} \mathrm{C}\right)$, leads to a decrease in foliage biomass value, to a slight decrease in branch biomass and remains unchanged in the aboveground and stem biomass.

Correspondingly, in water-rich areas $(P R=900 \mathrm{~mm})$, the rise in temperature causes a decrease of biomass values, and in moderate dry areas $(P R=400 \mathrm{~mm})$, in their increase. This pattern is opposite to the previously constructed analogous models for the aboveground biomass of two-needled pines (Usoltsev et al., 2019b) and larches (Usoltsev et al., 2019a). Perhaps this contradiction is due to the smaller ranges of temperature and precipitation in the areas occupied by oak stands, compared with pine and especially with larch ones, as well as due to biological features of coniferous and deciduous species. The regularities for pines and larches were previously confirmed by other authors on the local level (Glebov \& Litvinenko, 1976) and some regional levels (Molchanov, 1976; Polikarpov \& Chebakova, 1982).

Using the data of above- and underground biomass of 600 sample trees of eight larch species (genus Larix spp.) growing throughout China, the allometric model in- cluding the stem diameter and height as independent variables, was developed. After introduction into the allometric model the indices of the mean annual temperature and precipitation, as additional independent variables, it was established that the temperature increase by $1^{\circ} \mathrm{C}$ leads to an increase in the aboveground biomass of equal-sized trees by $0.9 \%$ and to a decrease in the underground one by $2.3 \%$, and an increase in precipitation by $100 \mathrm{~mm}$ causes a decrease in the above- and underground phytomass by 1.5 and $1.1 \%$, respectively (Zeng et al., 2017). Our results confirm the data by Zeng et al. (2017) related to the change in the aboveground biomass of larch trees with the increase in temperature by $1^{\circ} \mathrm{C}$, but only partly, namely in the areas of low precipitations. With the increase in precipitation by $100 \mathrm{~mm}$, we obtain the opposite result from Zeng's conclusion, namely an increase rather than a decrease in aboveground tree biomass. As had been mentioned above, this contradiction may be due to the smaller ranges of temperature and precipitation in the areas occupied by oak stands, as well as due to biological features of coniferous and deciduous species. 
In another study devoted to European forests (Forrester et al., 2017), there was no statistically significant effect of temperature and precipitation on the tree biomass of the most components. The reasons may be the following: a small range of temperature and precipitation variations within Europe, a study of species groups instead of a single species, the introduction of too many variables and their combined effects into the model, and the use of meta-data instead of harvest biomass indices.

The study of the regional variability of the allometric models of aboveground biomass of trees of Masson pine in southern China showed that diameter at breast height, together with the long-term average of growing season temperature, total growing season precipitation, mean temperature of wettest quarter, and precipitation of wettest quarter, had significant effects on values of aboveground biomass. Excessive precipitation during the growing season and high mean temperature in the wettest quarter reduced the aboveground biomass, while a warm growing season and abundant precipitation in the wettest quarter increased it (Fu et al., 2017). Thus, the reaction of pine biomass to the increase in precipitation in the subtropical conditions of China in the wettest quarter is negative, and in the wettest quarter at extremely high temperatures is positive. A similar differentiated reaction of biomass and net primary production to temperature and precipitation was shown earlier on the example of stands of two-needled pines in Eurasia (Usoltsev et al., 2019c). Apparently, any response of forests to climate change is species-specific and reflects the biological and ecological specificities of each tree species.

Our model obtained and the patterns shown are hypothetical: they reflect the long-term adaptive responses of forest stands to regional climatic conditions and do not take into account the rapid trends of current environmental changes, which place serious constraints on the ability of forests to adapt to new climatic conditions (Alcamo et al., 2007). Although modelling at the global level shows that the productivity of forest cover is mainly determined by temperature, other factors (salt stress, length of vegetative period, imbalance between air and soil temperatures, frost drought) limit the productivity to a much larger extent than just temperature. Besides, some experiments show clearly that the water status affects stomata opening and closing in very much degree, and our understanding of the adaptation to water shortage is still patchy (Schulze et al., 2005).

\section{Conclusions}

Thus, we have made the first attempt to simulate changes in the component composition of the aboveground biomass of oak trees by trans-Eurasian hydrothermal gradients, that revealed the presence of non-trivial regularities. The analy- sis of the aboveground biomass of oak trees on the basis of the component composition, using regression model method, showed changes in the structure of the biomass of trees, both in connection with the average temperature of January and average annual precipitation, namely: the intensity of changes in biomass due to temperature varies depending on the level of site moisture, and the intensity of changes in biomass due to the level of moisture changes during the transition from cold to warm temperature belts. The adequacy of the obtained regularities is determined by the level of variability $87-99 \%$ explained by the proposed regression models.

The obtained model of oak tree biomass make it possible to establish quantitative changes in the biomass structure due to climatic changes, in particular, the mean temperature of January and mean annual precipitation. The proposed additive model, adapted for use in the forest area of Eurasia, is designed for a more accurate assessment of the carbon-depositing ability of oak forests. However, this is a solution to the problem only in the first approximation, because it is based on a limited amount of harvest data.

\section{References}

Affleck D.L.R. \& Diéguez-Aranda U., 2016, Additive nonlinear biomass equations: a likelihood-based approach. Forest Science 62: 129-140. (https://doi.org/10.5849/ forsci.15-126).

Alcamo J., Moreno J.M., Nováky B., Bindi M., Corobov R., Devoy R.J.N, Giannakopoulos C., Martin E., Olesen J.E. \& Shvidenko A., 2007, Europe: impacts, adaptation and vulnerability. Contribution of Working Group II to the Fourth Assessment Report of the Intergovernmental Panel on Climate Change, [in:] M.L Parry., O.F. Canziani, J.P. Palutikof, P.J. van der Linden, C.E. Hanson (eds.) Climate change. Cambridge University Press, Cambridge: 541-580.

Baskerville G.L., 1972, Use of logarithmic regression in the estimation of plant biomass. Canadian Journal of Forest Research 2: 49-53.

Blunden J., Arndt D.S. \& Hartfield G. (eds.), 2018, State of the Climate in 2017. Bulletin of the American Meteorological Society 99(8): Si-S332. (https://doi.org/1 0.1175/2018BAMSStateoftheClimate.1).

Dahlberg U., Berge T.W., Petersson H. \& Vencatasawmy C.P., 2004, Modelling biomass and leaf area index in a sub-arctic Scandinavian mountain area. Scandinavian Journal of Forest Research 19: 60-71. (https://doi. org/10.1080/02827580310019266).

Davidson R.L., 1969, Effect of root/leaf temperature differentials on root/shoot ratios in some pasture grasses and clover. Annals of Botany (N.S.) 33(131): 561-569. 
de Miguel S., Mehtätalo L. \& Durkaya A., 2014, Developing generalized, calibratable, mixed-effects metamodels for large-scale biomass prediction. Canadian Journal of Forest Research 44: 648-656. (https://doi. org/10.1139/cjfr-2013-0385).

Dong L., Zhang L. \& Li F., 2015, A three-step proportional weighting system of nonlinear biomass equations. Forest Science 61: 35-45. (https://doi. org/10.5849/forsci.13-193).

Enquist B.J. \& Niklas K.J., 2001, Invariant scaling relations across tree-dominated communities. Nature 410: 655-660. (https://doi.org/10.1038/35070500).

Enquist B.J. \& Niklas K.J., 2002, Global allocation rules for patterns of biomass partitioning in seed plants. Science 295: 1517-1520. (https://doi.org/10.1126/science.1066360).

Felton A., Nilsson U., Sonesson J., Felton A.M., Roberge J.-M., Ranius T., Ahlström M., Bergh J., Bjorkman C., Boberg J., Drössler L., Fahlvik N., Gong P., Holmström E., Keskitalo E.C.H., Klapwijk M.J., Laudon H., Lundmark T., Niklasson M., Nordin A., Pettersson M., Stenlid J., Sténs A. \& Wallertz K., 2016, Replacing monocultures with mixed-species stands: Ecosystem service implications of two production forest alternatives in Sweden. Ambio 45(Suppl. 2): 124-139. (https://doi.org/10.1007/s13280-015-0749-2).

Fischer F.J., Marechaux I. \& Chave J., 2019, Improving plant allometry by fusing forest models and remote sensing. New Phytologist 21 March. (https://doi. org/10.1111/nph.15810).

Forrester D.I., Tachauer I.H.H., Annighoefer P., Barbeito I., Pretzsch H., Ruiz-Peinado R., Stark H., Vacchiano G., Zlatanov T., Chakraborty T., Saha S. \&, Sileshi G.W., 2017, Generalized biomass and leaf area allometric equations for European tree species incorporating stand structure, tree age and climate. Forest Ecology and Management 396: 160-175. (https://doi. org/10.1016/j.foreco.2017.04.011).

Fu L., Lei X., Hu Z., Zeng W., Tang Sh., Marshall P., Cao L., Song X., Yu L. \& Liang J., 2017, Integrating regional climate change into allometric equations for estimating tree aboveground biomass of Masson pine in China. Annals of Forest Science 74 (42): 1-15. (https://doi.org/10.1007/s13595-0170636-z).

Glebov F.Z. \& Litvinenko V.I., 1976, The dynamics of tree ring width in relation to meteorological indices in different types of wetland forests. Lesovedenie 4: 56-62 [in Russian].

Golubyatnikov L.L. \& Denisenko E.A., 2009, Influence of climatic changes on the vegetation of European Russia. News of Russian Academy of Sciences. Geographic series 2: 57-68 [in Russian].
Huber B., 1925, Die physiologische Leistungsfähigkeit des Wasserleitungssystems der Pflanze. Berichte der Deutschen Botanischen Gesellschaft 43: 410-418.

Huber B., 1927, Aus der Biologie der Baumkrone. Mitteilungen der Deutschen Den-drologischen Gesellschaft 38: 60-64.

Kazaryan V.O., 1969, Aging of higher plants. Nauka Publ., Moscow [in Russian].

Kozak A., 1970, Methods for ensuring additivity of biomass components by regression analysis. The Forestry Chronicle 46 (5): 402-404. (https://doi.org/10.5558/ tfc46402-5).

Laing J. \& Binyamin J., 2013, Climate change effect on winter temperature and precipitation of Yellowknife, Northwest Territories, Canada from 1943 to 2011. American Journal of Climate Change 2: 275-283. (https://doi.org/10.4236/ajcc.2013.24027).

Lakida P.I., Vasilishin R.D., Blishchik V.I., Bilous A.M., Matushevich L.M., Lashchenko A.G., Bala O.P., Mateiko I.M., Morozyuk O.V., Kovalevskiy S.S., Khan E.Yu., Sitnik S.A., Bokoch V.V., Blishchik I.V., Prilipko I.S., Mel'nik O.M. \& Dubrovets B.V., 2017, Deciduous forest stands of the Ukraine: phytomass and experimental data. FOP Gavrishenko V.M., Korsun'Shevchenkovskiy, 483 pp. [in Ukrainian].

Marklund L., 1987, Biomass functions for Norway spruce (Picea abies (L.) Karst) in Sweden. Report 43, Department of Forest Survey, SLU, Umea, 127 pp.

Molchanov A.A., 1976, Dendroclimatic fundamentals of weather forecasts. Moscow: Nauka Publishing, 168 pp. [in Russian].

Nikitin K.E., 1965, Forest and mathematics. Lesnoe Khozyaistvo [Forest Management] 5: 25-29 [in Russian].

Parresol B.R., 2001, Additivity of nonlinear biomass equations. Canadian Journal of Forest Research 31: 865-878. (https://doi.org/10.1139/cjfr-31-5-865).

Polikarpov N.P. \& Chebakova N.M., 1982, Evaluation of biological productivity of forest species on the ecological basis, [in:] Formation of young-growth stands of coniferous species. Nauka Publishing, Novosibirsk: 25-54 [in Russian].

Poorter H., Jagodzinski A.M., Ruiz-Peinado R., Kuyah S., Luo Y., Oleksyn J., Usoltsev V.A., Buckley T.N., Reich P.B. \& Sack L., 2015, How does biomass allocation change with size and differ among species? An analysis for 1200 plant species from five continents. New Phytologist 208(3): 736-749. (https://doi.org/10.1111/ nph.13571).

Riedel T. \& Kändler G., 2017, Nationale Treibhausgasberichterstattung: Neue Funktionen zur Schätzung der oberirdischen Biomasse am Einzelbaum. Forstarchiv 88 (2): 31-38. (https://doi.org/10.4432/0300-411288-31). 
Schulze D.-E., Beck E. \& Müller-Hohenstein K., 2005, Plant Ecology. Springer-Verlag, Berlin, Heidelberg, New York, 702 pp.

Shinozaki K., Yoda K., Hozumi K. \& Kira T., 1964a, A quantitative analysis of plant form - the pipe model theory. 1. Basic analysis. Japanese Journal of Ecology 14(3): 97-105.

Shinozaki K., Yoda K., Hozumi K. \& Kira T., 1964b, A quantitative analysis of plant form - the pipe model theory. 2. Further evidence of the theory and its application in forest ecology. Japanese Journal of Ecology 14(4): 133-139.

Usoltsev V.A., 1972, Birch and aspen crown biomass in forests of Northern Kazakhstan. Vestnik Selskokhozyaistvennoi Nauki Kazakhstana [Bulletin of Agricultural Science of Kazakhstan] 4: 77-80 [in Russian].

Usoltsev V.A., 1988, Growth and structure of forest stand biomass. Nauka Publ., Novosibirsk, 253 pp. [in Russian]. (http://elar.usfeu.ru/handle/123456789/3352).

Usoltsev V.A., 2007, Some methodological and conceptual uncertainties in estimating the income component of the forest carbon cycle. Russian Journal of Ecology 38(1): 11-10. (https://doi.org/10.1134/S1067413607010018).

Usoltsev V.A., 2016, Single-tree biomass of forest-forming species in Eurasia: database, climate-related geography, weight tables. Ural State Forest Engineering University, Yekaterinburg, 336 pp. (http://elar.usfeu.ru/handle/123456789/5696).

Usoltsev V.A., 2018, In basements of the biosphere: What we know about the primary production of tree roots? Eko-Potencial 4(24): 24-77 [in Russian]. (http://elar. usfeu.ru/bitstream/123456789/8024/1/eko4-18-04.pdf).

Usoltsev V.A., Zukow W., Osmirko A.A., Tsepordey I.S. \& Chasovskikh V.P., 2019a, Additive biomass models for Larix spp. single-trees sensitive to temperature and precipitation in Eurasia. Ecological Questions 30(2): 57-67. (http://dx.doi.org/10.12775/EQ.2019.012).

Usoltsev V.A., Tsepordey I.S. \& Chasovskikh V.P., 2019b, Tree biomass of two-needled pines in Eurasia: additive models in climatic gradients. Sibirskij Lesnoj Zurnal 1: 44-56 [in Russian with English abstract]. (https://doi. org/10.15372/SJFS20190104).

Usoltsev V.A., Shobairi, S.O.R., Tsepordey I.S., Chasovskikh V.P., 2019c, Modelling forest stand biomass and net primary production with the focus on additive models sensitive to climate variables for two-needled pines in Eurasia. Journal of Climate Change 5(1): 41-49. (https://doi.org/10.3233/JCC190005).
Vonderach C., Kändler G. \& Dormann C.F., 2018, Consistent set of additive biomass functions for eight tree species in Germany fit by nonlinear seemingly unrelated regression. Annals of Forest Science 75: 49 . (https:// doi.org/10.1007/s13595-018-0728-4).

West G.B., Brown J.H. \& Enquist B.J., 1997, A general model for the origin of allometric scaling laws in biology. Science 276(5309): 122-126. (https://doi. org/10.1126/science.276.5309.122).

West G.B., Brown J.H. \& Enguist B.J., 1999, A general model for the structure and allometry of plant vascular system. Nature 400: 664-667. (https://doi. org/10.1038/23251).

Williams M.S. \& Schreuder H.T., 2000, Guidelines for choosing volume equations in the presence of measurement error in height. Canadian Journal of Forest Research 30: 306-310. (https://doi.org/10.1139/x99-215).

World Weather Maps, 2007, URL. (https://www.mapsofworld.com/referrals/weather).

Zeng W.S., Chen X.Y., Pu Y. \& Yang X.Y., 2018, Comparison of different methods for estimating forest biomass and carbon storage based on National Forest Inventory data. Forest Research 31(1): 66-71 [in Chinese with English abstract]. (https://doi.org/10.13275/cnki. lykxyj.2017).

Zeng W.S., Duo H.R., Lei X.D., Chen X.Y., Wang X.J., Pu Y. \& Zou W.T., 2017, Individual tree biomass equations and growth models sensitive to climate variables for Larix spp. in China. European Journal of Forest Research 136(20): 233-249. (https://doi.org/10.1007/ s10342-017-1024-9).

Zhang C., Peng D.-L., Huang G.-S. \& Zeng W.-S., 2016, Developing aboveground biomass equations both compatible with tree volume equations and additive systems for single-trees in poplar plantations in Jiangsu Province, China. Forests 7(2): 32. (https://doi.org/10.3390/ f7020032).

Zheng C., Mason E.G., Jia L., Wei S., Sun C. \& Duan J., 2015, A single-tree additive biomass model of Quercus variabilis Blume forests in North China. Trees 29(3): 705-716. (https://doi.org/10.1007/s00468-014-1148-1).

Zianis D., Muukkonen P., Makipaa R. \& Mencuccini M., 2005, Biomass and stem volume equations for tree species in Europe. Silva Fennica Monograph 1-2: 5-63. (https://silvafennica.fi/pdf/smf004.pdf). 


\title{
Elements distribution in soil and plants of an old copper slag dump in the Middle Urals, Russia
}

\author{
Ekaterina Zolotova*, Viktor Ryabinin \\ Zavaritsky Institute of Geology and Geochemistry, Ural Branch of Russian Academy of Sciences, \\ 15 Akad. Vonsovsky street, Yekaterinburg, Russia, 620016 \\ *e-mail: afalinakate@gmail.com
}

Received: 17 April 2019 / Accepted: 8 November 2019

\begin{abstract}
The elements concentration in soil and accumulation in plants growing spontaneously on an old copper slag dump were studied. The research object was a landfill site of the Polevskoy copper smelter (Middle Ural, Russia), which is about 200 years old. We investigated composite samples, consisting of soil blocks $(20 \times 20 \mathrm{~cm})$ with growing plants. Samples were selected on a transect of 4-5 $\mathrm{m}$ at equal intervals. The composite sample was divided into slag fractions: stone, gravel, fine soil (particles smaller than $1 \mathrm{~mm}$ ); plant fractions: moss and roots, stems and leaves. The microelement analysis of the samples was carried out at an analytical center of the Institute of Geology and Geochemistry, Ural Branch of RAS. The analyses were performed by inductively coupled plasma mass-spectrometry using Elan-9000 ICP mass-spectrometer. The formation of technogenic soil with a thickness of 10-15 cm on the dump of cast copper slag has begun two hundred years ago. Fine soil constitutes more than one third of the technogenic soil mass and acts as a sorption geochemical barrier. Fine soil accumulates elements mobilized from slag. The concentration of most elements in fine soil is 1-2 orders of magnitude higher than their concentration in slag stone. $\mathrm{Pb}, \mathrm{Cd}, \mathrm{Bi}$ are particularly effectively retained in fine soil: their content is 700-1000 times higher than in slag stone. In the conditions of unlimited supply of elements released from slag, plant reaches the upper threshold of accumulation. The aboveground plant parts compared to litter (roots and moss) have a lower concentration of all elements, but they show the stronger ability to accumulate selenium.
\end{abstract}

Keywords: industrial dump, heavy metals, technogenic soil, anthropogenic ecosystems, elements distribution.

\section{Introduction}

Extraction and processing of minerals leads to soil degradation, natural ecosystems and landscapes destruction, rivers and groundwater pollution, the industrial waste dumps formation (Chibrik et al., 2011; Mensah et al., 2015).

Mining and mineral processing wastes occupy vast areas around the world, disfigures the environment and are pollution sources. Soil and vegetation restoration in manmade landscapes occurs in two variants: reclamation and spontaneous revegetation. Studies of spontaneous revegetation are necessary for the development of man-made territories biological reclamation. The result of success- ful biological reclamation is a sustainable, productive and economically valuable ecosystems (Chibrik et al., 2011; Vymazal \& Sklenicka, 2012)

Spontaneous revegetation of dumps occurs in most cases are extremely slow and with specific features of the soil and plants restoration, which depend on the dumps nature. It should be remembered that plants are able to concentrate certain elements in quantities that are dangerous when included in food chains. Therefore, it is necessary to evaluation the chemical composition of plants growing on dumps (Remon et al., 2005).

Industrial dumps are numerous and diverse. The basis of Russian classification (Tarchevsky, 1970) is the dumps 
origin (mining industry dumps, processing dumps or other), and the remaining features (age, shape, height, mechanical composition of the surface substrate, acidity, the recycling possibility) are explanatory and can be used to characterize all types of dumps.

The features of the soil formation process are quite well considered for the ash dumps of thermal power stations (Zikeli et al., 2002; Uzarowicz \& Zagórski, 2015; Konstantinov et al., 2018) and mining waste (Sourkova et al., 2005; Bragina \& Gerasimova, 2014; Santini \& Banning, 2016; Dvurechensky et al., 2018), but significantly worse for the metallurgy slag dumps. We have found interesting studies of Polish scientists about old pyrometallurgical copper slags (Kierczak et al., 2013). The article considers mineralogical and chemical composition of slags, and the authors attempt to assess the elements migration into soils, river sediments and surface waters.

Vegetation formation is also much more detailed studied for the ash dumps (Makhnev et al., 2002; Glazyrina et al., 2016; Chibrik et al., 2018) and dumps of different deposits (Kupriyanov et al., 2010; Josu et al., 2012; Glazyrina et al., 2016; Lukina et al., 2017), including copper ore (Zheleva et al., 2012; Avensio et al., 2013).

The Ural is a historically developed industrial region, one of the most powerful in Russia. The mining industry has been intensively developing since the beginning of the 20th century. The region is characterized by the presence of large areas of old industrial dumps, where for many decades the natural restoration of soil and vegetation took place. Therefore, the Urals are an excellent research site for research spontaneous revegetation of industrial dumps (Makhnev et al., 2002; Glazyrina et al., 2016; Lukina et al., 2017; Chibrik et al., 2018), and studying the structure and properties of technogenic soils (Makhonina, 2003). However, many questions about the restoration and transformation of vegetation and soil on industrial dumps, especially metallurgical slags, have remained little studied. Single studies about assess the soils and vegetation geochemical transformation in the copper industry dumps (Pasynkova, 1997) are found.

Some studies state that old copper smelting slags are often more dangerous for the environment than modern production wastes, since they were placed uncontrollably, in direct contact with the soil, surface water and groundwater. Old copper smelting slags also contain more potentially toxic elements than modern slags exposed to more technological and advanced smelting processes (Piatak et al., 2004; Vítková et al., 2010; Kierczak et al., 2013).

In connection with the above researches of the chemical composition of technogenic soil and plants in one of the oldest copper slag dumps in the Urals are great interest. The our research purpose was to study of the elements distribution in soil and plants growing spontaneously on the old Polevsky copper smelter dump. Similar studies for this facility have not been conducted.

\section{Materials and methods}

Polevskoy copper smelter is one of the oldest copper smelters and iron smelters in the Urals. It was located on the Dumnaya mountain on the bank of the Polevaya river, a tributary of the Chusovaya river, 52 kilometers southwest of Yekaterinburg (Fig. 1). The coordinates of the study area are $56^{\circ} 26^{\prime} 22^{\prime \prime} \mathrm{N}, 60^{\circ} 11^{\prime} 22^{\prime \prime} \mathrm{E}$. The climate is temper-

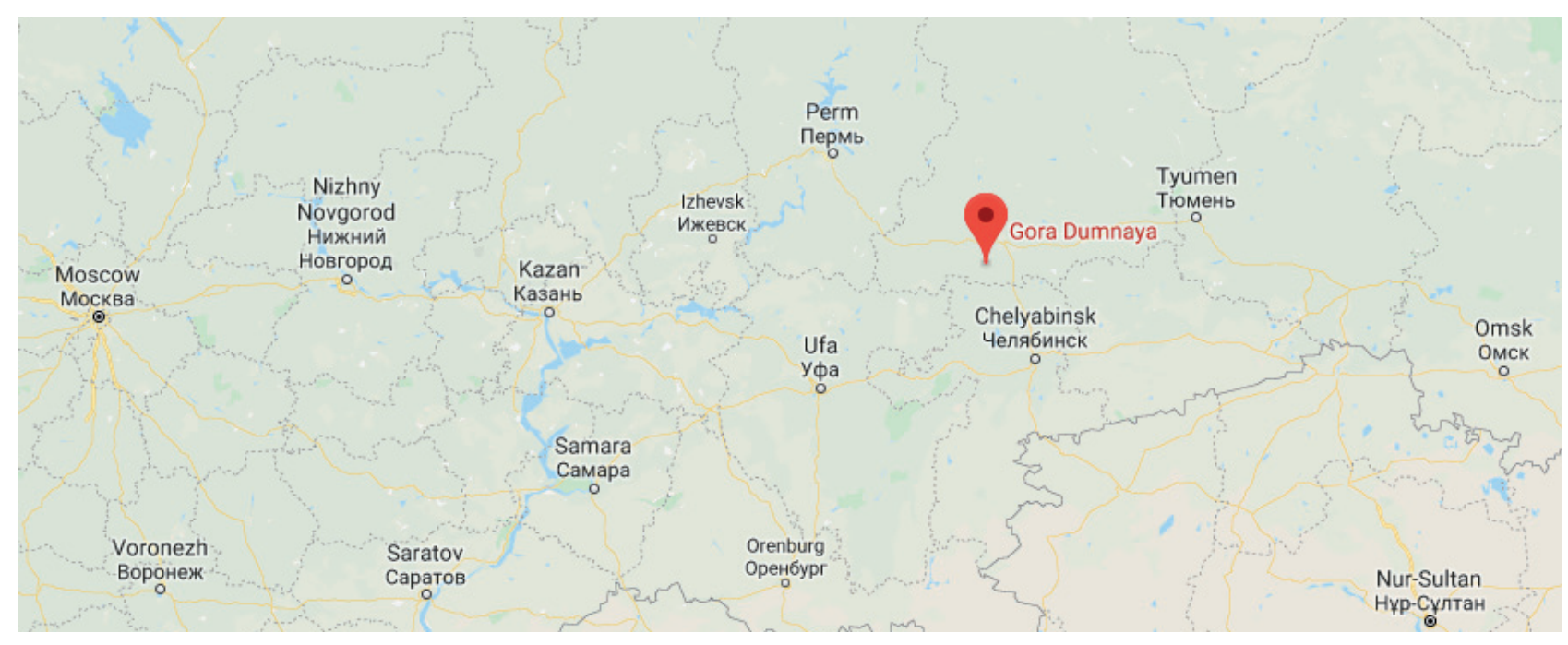

Figure 1. Map of the research area with its location in Russia 
ate continental. Snow cover is established in November and lasts until April. The depth of soil freezing is $1.25 \mathrm{~m}$. The prevailing winds are westerly and southwesterly. The study area belongs to the Middle Ural taiga region (according to the list of forest growing zones and forest regions of the Russian Federation), and to the border of forest growing district identified according to the classification of B.P. Kolesnikov (Kolesnikov et al., 1973): the south taiga forest district of the Trans-Ural hilly foothill province. In the area of the Polevskoy town the primary forests were not preserved, clear cutting was carried out. Derived mixed forests grow.

Polevskoy copper smelter was founded in 1724 and worked until 1930. The oxidation zone of skarn deposit was processed as ore. The technology of producing copper is a mine smelting method. The dump as a result of the activity of Polevskoy copper smelter was formed and has survived to the present day as a steep hill, which is a continuation of the northwestern slope of Dumnaya mountain. A mixed forest with a predominance of birch grows on top of the mountain.

The research object is the Polevskoy copper smelter dump, on which technogenic soil and plants spontaneously growing were formed. The dump is about two hundred years old. According to the classification of V.V. Tarchevsky (1970) the research object refers to bulk medium height (about 10 meters) dumps of the processing industry.

The copper smelting slag of the studied dump is represented by angular black fragments of various sizes with a porous inhomogeneous structure. Oxidation processes are characteristic of the slags; brown iron hydroxides develop along cleavage planes and the upper porous part. The composition of the copper smelting slag includes: manmade silicate glass, pyroxene, magnetite and minerals related to ferrites (Makarov et al., 2018).

We laid the sample plot on a relatively flat terrassoid section of the foot of the northwestern steep slope of the copper smelting dump. The technogenic soil profile was $10-15 \mathrm{~cm}$ and looked like a layer of mostly fine-grained material, which covers coarse-grained crushed stone of the slag. The soil has ensured the development of mixed grass vegetation. The plant roots develop within the dense moss cover and together form a litter.

Soil blocks $(20 \times 20 \mathrm{~cm})$ together with growing plants on a transect of 4-5 m were selected at equal intervals for the our research purpose. The transect was laid along the foot of the dump on a relatively flat section. The main environmental gradients (altitude, humidity, lighting) are the same. The composite sample included four plots $20 \mathrm{x}$ $20 \mathrm{~cm}$. Soil was collected up to the parent rock (slag). The thickness of the soil profile was $10-15 \mathrm{~cm}$. Plant stems with leaves were cut at the root. The material of the composite sample was divided into natural fractions (soil, plants) and according to the size of copper slag fragments, then airdried and weighed (Table 1).

Each fraction of the composite sample was analysed in the chemical laboratory of the Zavaritsky Institute of Geology and Geochemistry of the Ural Branch of the Russian Academy of Sciences. The microelements composition of the samples was determined by inductively coupled plasma mass-spectrometry using Elan-9000 ICP mass-spectrometer. The sample preparation was performed by acid decomposition, followed by autoclave mineralization in the microwave oven. The obtained element concentrations agree with available reference values to a tolerance of about $15 \%$.

\section{Results and discussion}

Man-made ecosystems are very different from natural ones primarily by the lack of a developed soil profile, morphological parameters and properties of the substrate, the structure and productivity of the plant community, and the circulation of matter and energy (Makhonina, 2003; Sibirin et al., 2012).

The investigated technogenic soil of the old Polevskoy copper smelter dump mainly consist of slag particles less than $1 \mathrm{~mm}$. The abundance of fine soil at the dump base may indicate that subsidence of the fine fraction to the

Table 1. Mass of fractions of the composite sample collected at the old copper slag dump (Middle Ural, Russia)

\begin{tabular}{|l|l|c|}
\hline \multicolumn{1}{|c|}{ Fractions of the sample } & \multicolumn{1}{c|}{ Composition of the sample } & Fraction mass \\
\hline Stone & Slag particles over $5 \mathrm{~mm}$ & $32.63 \%$ \\
\hline Gravel & Slag particles $1-5 \mathrm{~mm}$ & $21.98 \%$ \\
\hline Fine soil & Slag particles smaller than $1 \mathrm{~mm}$ & $37.55 \%$ \\
\hline Litter (plant roots and moss) & - & $1.43 \%$ \\
\hline Plant stems and leaves & - & $6.41 \%$ \\
\hline
\end{tabular}


deeper horizons of slag rubble, partial flushing, and accumulation at the foot of the dump slope occurred.

The results of the elemental analysis of the investigated composite sample are presented in Table 2. The chemical composition of the large fraction of the soil sample (slag particles over $5 \mathrm{~mm}$ ) should be taken as the average composition of the soil-forming slag. Mainly all the chemical elements (except Al, V, Cr, Mn, Se, Mn) show signs of accumulation already at the first stage of the stone disintegration - in gravel. The most elements content in gravel is noticeably higher than in stone of slag. The maximum accumulation of all elements occurs in the fine soil (slag particles less than $1 \mathrm{~mm}$ ). We explain the abnormally high content of elements by the fact that the part of the dissolved slag components were washed down along the the slope and sorbed by fine soil from the solu- tion at the foot of the dump slope. The content of deposited $\mathrm{Pb}, \mathrm{Cd}$ and $\mathrm{Bi}$ is especially high, their content in the fine soil is 700-1000 times higher than in stone of slag. The smallest differences in the elements concentrations contained in stone and fine soil of old copper slag dump were found for $\mathrm{Zn}, \mathrm{Sb}, \mathrm{As}, \mathrm{Cu}, \mathrm{Hg}, \mathrm{B}$ and $\mathrm{Ca}$; they concentrations are 100-200 times larger in the fine soil than in the stone.

We used the maximum permissible concentration of total forms of elements (MPC) and concentration coefficient relative to the MPC (Table 3) for ecotoxicological assessment of technogenic soil. Concentration coefficient relative to the MPC is equal to the ratio of the element content in the soil to its maximum permissible concentrations. Maximum permissible concentrations of dangerous chemical elements are regulated in Russia by state documents for

Table 2. The distribution of chemical elements (total, $\mathrm{mg} / \mathrm{kg}$ ) by fractions of the composite sample of the old copper slag dump (Middle Ural, Russia)

\begin{tabular}{|c|c|c|c|c|c|}
\hline Element & Stone & Gravel & Fine soil & Litter (plant roots, moss) & Plant stems, leaves \\
\hline $\mathrm{B}$ & 7.19 & 10.0 & 1,031 & 24.3 & 6.33 \\
\hline $\mathrm{Mg}$ & 8,347 & 12,159 & 351,666 & 9,838 & 674 \\
\hline $\mathrm{Al}$ & 11,271 & 10,619 & 765,271 & 26,779 & 853 \\
\hline $\mathrm{P}$ & 1,840 & 2,215 & 78,628 & 1,691 & 656 \\
\hline $\mathrm{K}$ & 2,167 & 3,661 & 197,295 & 5,060 & 3,632 \\
\hline $\mathrm{Ca}$ & 3,158 & 5,989 & 568,731 & 15,688 & 4,620 \\
\hline V & 116 & 84.1 & 2210 & 44.4 & 1.19 \\
\hline $\mathrm{Cr}$ & 830 & 754 & 11,145 & 187 & 3.33 \\
\hline $\mathrm{Mn}$ & 6,038 & 5,178 & 101,630 & 1,924 & 55.0 \\
\hline $\mathrm{Co}$ & 46.4 & 66.3 & 2,282 & 33.6 & 0.984 \\
\hline $\mathrm{Ni}$ & 220 & 507 & 19,035 & 233 & 4.79 \\
\hline $\mathrm{Cu}$ & 201 & 243 & 21,391 & 497 & 18.0 \\
\hline $\mathrm{Zn}$ & 37.6 & 78.0 & 9,137 & 163 & 53.8 \\
\hline As & 9.62 & 14.0 & 999 & 11.6 & 0.555 \\
\hline $\mathrm{Se}$ & 20.0 & - & 984 & 49.9 & 206 \\
\hline Mo & 2.03 & 1.86 & 67.1 & 1.47 & 0.394 \\
\hline $\mathrm{Cd}$ & 0.062 & 0.217 & 56.1 & 1.43 & 0.393 \\
\hline $\mathrm{Sb}$ & 1.08 & 1.79 & 170 & 2.66 & 0.178 \\
\hline $\mathrm{Hg}$ & 1.05 & 1.37 & 118 & 2.14 & 0.396 \\
\hline $\mathrm{Pb}$ & 13.4 & 103 & 14,623 & 140 & 13.0 \\
\hline $\mathrm{Bi}$ & 0.038 & 0.104 & 27.4 & 0.449 & 0.089 \\
\hline
\end{tabular}


environmental objects: for soil this is GN 2.1.7.2041-06 (GN, 2006).

The concentrations of $\mathrm{As}, \mathrm{Mn}, \mathrm{Cu}, \mathrm{Ni}$ exceeded the maximum permissible concentration of elements in all mineral fractions of technogenic soil (stone, gravel, fine soil). The most significant excess concentrations for heavy metals were in the fine soil. Concentrations of $\mathrm{As}, \mathrm{Pb}, \mathrm{Cu}$, Ni were 499, 457, 389, 224 times of the maximum permissible concentration (Table 3), respectively.

Plants absorb almost all chemical elements from the environment. Some elements are necessary for metabolic processes, however, in high concentrations they become toxic for plants, other elements, such as $\mathrm{Pb}, \mathrm{Cd}$, are toxic even in low concentrations (Baker, 1981). The mechanisms of plant resistance are manifested in different directions: some species are able to accumulate high concentrations of heavy metals, but are tolerant to them; others plants seek to reduce their intake by maximizing the use of barrier functions. The first barrier level is the roots, where the largest amount of heavy metals is retained, the next is the stems and leaves, and finally, the last barrier is the organs and parts of plants responsible for reproductive functions (most often seeds and fruits, as well as root and tuber crops) (Ilyin \& Syso, 2001).

For the studied soil litter (mosses and plant roots), most elements (B, Al, K, Ca, Cu, Zn, Se, Cd, Sb, Hg, Pb, Bi) are in concentrations higher than in stone of slag dump, but lower than in fine soil. Probably, the upper threshold of accumulation of these elements in the plant roots and mosses is reached. Despite the abundance of available forms of metals, their further entry into the plants does not occur. Another group of elements ( $, \mathrm{Cr}, \mathrm{Mn}, \mathrm{Co}$, $\mathrm{Mo}$ ) is found in mosses and plant roots in lower concentrations relative to the stone of slag dump, which reflects their lower accumulation threshold. Perhaps the explanation of the identified features in the elements distribution is simplified. The elements migration from soil to plants is a complex and multifactorial process. Analysis of scientific articles showed that a significant positive correlation exists between the metal concentration in soils and some plant species, however for other plant species, for example such as Silene paradoxa, does not exist (Pignattelli et al., 2012).

Aboveground parts of plants have a lower accumulation threshold for all components compared to the litter. However, the content of such chalcophilic elements as Se, $\mathrm{Zn}, \mathrm{Cd}$ and $\mathrm{Bi}$ in plant stems and leaves exceeds that in the stone of the old copper slag dump. The peculiarity of the aboveground parts of plants is the accumulation of selenium.

Potassium and calcium are important elements for vegetation, their concentrations in the plant stems are commensurate with the content of $\mathrm{K}$ and $\mathrm{Ca}$ in the stone of slag dump. However, the concentrations of $\mathrm{Mg}$ and $\mathrm{P}$ in the

Table 3. The ecological assessment of technogenic soil using the element concentration coefficient relative to the maximum permissible concentration

\begin{tabular}{|c|c|c|c|c|}
\hline \multirow{2}{*}{ Element } & \multirow{2}{*}{$\begin{array}{l}\text { Maximum permissible } \\
\text { concentrations, } \mathrm{mg} / \mathrm{kg}\end{array}$} & \multicolumn{3}{|c|}{$\begin{array}{l}\text { Concentration coefficient relative } \\
\text { to the maximum permissible concentration }\end{array}$} \\
\hline & & Stone & Gravel & Fine soil \\
\hline $\mathrm{V}$ & 150.0 & 0.770 & 0.560 & 14.7 \\
\hline $\mathrm{Mn}$ & 1,500 & 4.03 & 3.45 & 67.8 \\
\hline $\mathrm{V}+\mathrm{Mn}$ & $100+1,000$ & 5.59 & 4.78 & 94.4 \\
\hline As & 2.0 & 4.81 & 6.99 & 499 \\
\hline $\mathrm{Sb}$ & 4.5 & 0.239 & 0.399 & 37.9 \\
\hline $\mathrm{Hg}$ & 2.1 & 0.501 & 0.652 & 56.5 \\
\hline $\mathrm{Pb}$ & 32.0 & 0.420 & 3.23 & 457 \\
\hline $\mathrm{Pb}+\mathrm{Hg}$ & $20.0+1.0$ & 0.690 & 4.99 & 702 \\
\hline $\mathrm{Cu}^{*}$ & 55 & 3.65 & 4.42 & 389 \\
\hline $\mathrm{Zn} *$ & 100 & 0.376 & 0.780 & 91.4 \\
\hline $\mathrm{Ni}^{*}$ & 85 & 2.59 & 5.97 & 224 \\
\hline
\end{tabular}

* - The approximate values are given in the earlier government document on the regulation of the content of elements in the soil. 
plant stems are significantly less than in slag, despite the recognized high biophilicity.

We calculated the biological absorption coefficients to assess the degree of accumulation of heavy metals by plants. Biological absorption coefficient is the ratio of the content of an element in a plant to the total content of this element in the soil (in our case - fine soil of slag). Visual series of accumulation were compiled. For different parts of the plant sample, an increase in the biological absorption coefficients is as follows:

1. Plant roots and moss:

$\mathrm{Pb}-\mathrm{As}-\mathrm{Ni}-\mathrm{Co}-\mathrm{Sb}-\mathrm{Bi}-\mathrm{Cr}-\mathrm{Zn}-\mathrm{Hg}-\mathrm{Mn}-\mathrm{V}-(\mathrm{Mo}, \mathrm{P})-$ $-\mathrm{Cu}-\mathrm{B}-\mathrm{Cd}-\mathrm{K}-(\mathrm{Ca}, \mathrm{Mg})-\mathrm{Al}-\mathrm{Se}$

The biological absorption coefficients are greatest for selenium (0.051), aluminum (0.035), calcium (0.028) and magnesium (0.028).

2. Plant stems and leaves:

$\mathrm{Ni}-\mathrm{Cr}-\mathrm{Bi}-\mathrm{Co}-(\mathrm{V}, \mathrm{Mn})-\mathrm{As}-\mathrm{Cu}-\mathrm{Pb}-(\mathrm{Sb}, \mathrm{Al})-\mathrm{Mg}-\mathrm{Hg}-$ $-(\mathrm{Mo}, \mathrm{Zn}, \mathrm{B})-\mathrm{Cd}-(\mathrm{Ca}, \mathrm{P})-\mathrm{K}-\mathrm{Se}$

The highest biological absorption coefficients in plant stems and leaves was found for selenium (0.21), potassium (0.018), calcium (0.08) and phosphorus (0.08).

\section{Conclusion}

For two hundred years, the technogenic soil with a capacity of 10-15 cm was formed on the old copper slag dump. Fine soil is more than a third of the mass of technogenic soil and is a sorption geochemical barrier. Fine soil accumulates the elements mobilized from slag. The concentration of most elements in the fine soil by 1-2 orders of magnitude higher than the concentration in the stone of slag. $\mathrm{Pb}, \mathrm{Cd}, \mathrm{Bi}$ are especially effectively retained in the fine soil: their content is 700-1000 times higher than in slag stone. Concentrations of As, Pb, Cu, Ni were 499, 457, 389, 224 times of the maximum permissible concentration.

The plants growing spontaneously on an old copper slag dump has an upper threshold of accumulation in the conditions of a large stock of elements migrating from slag. Litter (plant roots and moss) deposit almost the entire range of elements of copper smelting slag. The biological absorption coefficients (from fine soil) are greatest for selenium (0.051) and aluminum (0.035). The plant stems and leaves in comparison with the litter have a lower concentration of all elements, but they show the stronger ability to accumulate selenium (biological absorption coefficient is 0.21 ).

\section{Acknowledgments}

The study was performed in the framework of the state assignment of the Zavaritsky Institute of Geology and Geo- chemistry, Ural Branch of Russian Academy of Sciences (state registration number AAAA-A18-118052590028-9).

\section{References}

Asensio V., Vega F.A., Andrade M.L. \& Covelo E.F., 2013, Tree vegetation and waste amendments to improve the physical condition of copper mine soils. Chemosphere 90 (2): 603-610. (doi:10.1016/j.chemosphere.2012.08.050).

Baker A.J.M., 1981, Accumulators and excluders strategies in the response of plants to heavy metals. J. Plant Nutr. 3(1/4): 643-654.

Bragina P.S. \& Gerasimova M.I., 2014, Pedogenic processes on mining dumps (a case study of southern Kemerovo oblast). Geography and Natural Resources 35 (1): 35-40.

Chibrik T.S., Lukina N.V., Filimonova E.I. \& Glazyrina M.A., 2011, Ecological foundations and experience of biological reclamation of lands disturbed by industry. Ural University Press, Yekaterinburg, 267 pp.

Chibrik T.S., Lukina N.V., Filimonova E.I., Glazyrina M.A. \& Rakov E.A., 2018, Phytocenosis formation at the Nizhneturinskaya power station ash dumps. Regional Environmental Issues (Problemy regional'noj ehkologii) 6: 27-29. (doi: 10.24411/1728-323X-2019-16027).

Dvurechensky V.G., Sokolov D.A. \& Seredina V.P., 2018, Qualitative assessment of souls in technogenic landscapesof Gorlovskiy anthracitous deposit. Bulletin of NSAU (Novosibirsk State Agrarian University) 3(48): 53-61. (doi:10.31677/2072-6724-2018-48-353-61).

Glazyrina M.A., Filimonova E.I., Lukina N.V. \& Chibrik T.S., 2016, Study of plant populations on industrial dumps. Ural University Press, Yekaterinburg, 228 pp.

GN 2.1.7.2041-06, 2006, Predel'no dopustimye koncentracii (PDK) himicheskih veshchestv v pochve [Maximum permissible concentration (MPC) of chemicals in the soil], 6 pp.

Ilyin V.B. \& Syso A.I., 2001, Trace elements and heavy metals in soils and plants of the Novosibirsk region. Publisher SB RAS, Novosibirsk, 231 pp.

Josu G., Alday J.G., Marrs R.H. \& Martínez-Ruiz C., 2012, Soil and vegetation development during early succession on restored coal wastes: a six-year permanent plot study. Plant Soil 353: 305. (doi:10.1007/s11104-0111033-2).

Kierczak J., Potysz A., Pietranik A., Tyszka R., Modelska M., Néel C., Ettler V. \& Mihaljevič M., 2013, Environmental impact of the historical $\mathrm{Cu}$ smelting in the Rudawy Janowickie Mountains (south-western Poland). Journal of Geochemical Exploration 124: 183-194. 
Kolesnikov B.P., Zubareva R.S., Smolonogov E.P., 1973, Forest vegetation conditions and forest types of the Sverdlovsk region. UNTS of Academy of Science of the USSR, Sverdlovsk, $176 \mathrm{pp}$.

Konstantinov A.O., Novoselov A.A. \& Loiko S.V., 2018, Special features of soil development within overgrowing fly ash deposit sites of the solid fuel power plant. Tomsk State University Journal of Biology 43: 6-24. (doi: 10.17223/19988591/43/1).

Kupriyanov A.N., Manakov Yu.A. \& Barannik L.P., 2010, Restoration of ecosystems in the dumps of the mining industry of Kuzbass. Academic Publishing House “Geo", Novosibirsk, 160 pp.

Lukina N.V., Glazyrin M.A., Filimonova E.I., Chibrik T.S \& Shapovalova K.I., 2017, Formation the vegetation on Bazhenovskiy deposit of chrysotile-asbestos. Izvestia of Samara Scientific Center of the Russian Academy of Sciences 19(2/2): 294-299.

Makarov A.B., Khasanova G.G., Koinov S.A., 2018. Mineralogical and geochemical features starreally toxins Polevsky copper-smelting plant (the Middle Urals, Sverdlovsk region). Problemy mineralogii, petrografii I metallogenii. Nauchnye chteniya pamyati P.N. Chirvinskogo [Problems of mineralogy, petrography and metallogeny. Scientific readings of memory P.N. Chirvinsky] 21: 430-435.

Makhonina G.I., 2003, Ecological aspects of soil formation in the technogenic ecosystems of the Urals. Ural University Publishing House, Yekaterinburg, 356 pp.

Makhnev A.K., Chibrik T.S., Trubina M.R., Lukina N.V., Gebel' N.E., Terin A.A., Elovikov Yu.I., Toporkov N.V., 2002, Ekologicheskie osnovy i metody biologicheskoy rekul'tivatsii zolootvalov teplovykh elektrostantsiy na Urale [Ecological bases and methods of biological recultivation of ash dumps of thermal power stations in the Urals]. Ural Branch of the Russian Academy of Sciences Publishing, Yekaterinburg, 356 pp.

Mensah A.K., Mahiri I.O., Owusu O., Mireku O.D., Wireko I. \& Kissi E.A., 2015, Environmental Impacts of Mining: A Study of Mining Communities in Ghana. Applied Ecology and Environmental Sciences 3(3): 81-94. (doi:10.12691/aees-3-3-3).

Pasynkova M.V., 1997, Heavy metals in the soil - plant system on the dumps of the copper industry. Ecological Studies in the Urals. Ural State University, Yekaterinburg: 120-133.

Piatak N.M., Seal II R.R. \& Hammarstrom J.M., 2004, Mineralogical and geochemical controls on the release of trace elements from slag produced by base- and precious-metal smelting at abandoned mine sites. Applied Geochemistry 19: 1039-1064.
Pignattelli S., Colzi I., Buccianti A., Cecchi L., Arnetoli M., Monnanni R., R.Gabbrielli R., Gonnelli C., 2012, Exploring element accumulation patterns of a metal excluder plant naturally colonizing a highly contaminated soil. Journal of Hazardous Materials 227-228: 362-369. (doi:10.1016/j.jhazmat.2012.05.075).

Remon E., Bouchardon J.-L., Cornier B., Guy B., Leclerc J.-C. \& Faure O., 2005, Soil characteristics, heavy metal availability and vegetation recovery at a former metallurgical landfill: Implications in risk assessment and site restoration. Environmental Pollution 137(2): 316-323. (doi:10.1016/j.envpol.2005.01.012).

Santini T.C. \& Banning N.C., 2016, Alkaline tailings as novel soil forming substrates: Reframing perspectives on mining and refining wastes. Hydrometallurgy 164: 38-47. (doi:10.1016/j.hydromet.2016.04.011).

Sibirina L.A., Polokhin O.V. \& Zhabyko E.V., 2012, Initial stages of the formation of plant cover on industrycaused ecotopes of the Primorsky territory. Izvestia of Samara Scientific Center of the Russian Academy of Sciences 14(1/6): 1539-1542.

Sourkova M., Frouz J. \& Santruckova H., 2005, Accumulation of carbon, nitrogen and phosphorus during soil formation on alder spoil heaps after brown-coal mining, near Sokolov (Czech Republic). Geoderma 124: 203-214.

Tarchevsky V.V., 1970, Classification of industrial dumps, [in:] Vegetation and industrial pollution: The Nature Conservation in the Urals. Sverdlovsk: 84-89.

Uzarowicz Ł. \& Zagórski Z., 2015, Mineralogy and chemical composition of technogenic soils (Technosols) developed from fly ash and bottom ash from selected thermal power stations in Poland. Soil Science Annual 66(2): 82-91.

Vítková M., Ettler V., Johan Z., Kříbek B., Šebek O. \& Mihaljevič M., 2010, Primary and secondary phases in copper-cobalt smelting slags from the Copperbelt Province, Zambia. Mineralogical Magazine 74: 581-600.

Vymazal J. \& Sklenicka P., 2012, Restoration of areas affected by mining. Ecological Engineering 43: 1-4.

Zheleva E.I., Bozhinova P.M. \& Venelinov M.A., 2012, Phytocenological characteristics of bulk of rock overburdened dumps of mine "Ellatzite". Biological recultivation and monitoring of disturbed industrial lands. Ural University Press, Yekaterinburg: 103-112.

Zikeli S., Jahn R. \& Kastler M., 2002, Initial soil development in lignite ash landfills and settling ponds in Saxony-Anhalt, Germany. Journal of Soil Science and Plant Nutrition 165: 530-536. (doi:10.1016/j.hydromet.2016.04.011). 



\title{
Biomass structure of Pinus sylvestris and Betula pendula forest ecosystems in pollution gradient near copper plant on the Southern Ural
}

\author{
Vladimir A. Usoltsev ${ }^{1,2}$, Walery Zukow ${ }^{3 *}$, Viktor P. Chasovskikh ${ }^{1}$ \\ ${ }^{1}$ Ural State Forest Engineering University Sibirskii trakt str., 37, Yekaterinburg, 620100 Russian Federation \\ ${ }^{2}$ Botanical Garden, Russian Academy of Sciences, Ural Branch, 8 Marta str., 202a, \\ Yekaterinburg, 620144 Russian Federation \\ ${ }^{3}$ Faculty of Earth Sciences and Spatial Management, Nicolaus Copernicus University, Lwowska 1 str., \\ 87-100 Toruń, Poland, \\ *e-mail: zukow@umk.pl
}

Received: 25 September 2019 / Accepted: 29 October 2019

\begin{abstract}
In the gradient of pollution from the Karabash copper smelter in the Southern Urals $\left(55^{\circ} 29^{\prime} \mathrm{N}, 60^{\circ} 13^{\prime} \mathrm{E}\right)$ in predominantly pure Scots pine and white birch stands, 12 and 34 sample plots are established, respectively, on which 42 and 56 model trees are taken, respectively, by stem diameter. The pollution gradient is expressed by the toxicity index suggested with a relative index of the content in the litter of three "technogenic" metals $\mathrm{Cu}, \mathrm{Pb}$ and $\mathrm{Fe}$. Regression analysis of the dependence of biomass and NPP of trees and stands from toxicity index is performed. There is a log-log-linear pattern of reduction of biomass and annual NPP of spruce-fir forest stands with increasing toxicity index in the direction to the source of pollution, but for the biomass of trees in the same gradient no consistent pattern is detected. The dry matter content (DMC) in all biomass components depends on the toxicity index and species at a statistically significant level: due to the increase in the toxicity index, it decreases in wood and bark, and increases in foliage and branches. At the same toxicity index, DMC in the branches and stem wood more in birch, but in the bark and foliage - in pine. In the wood and bark of a stem, this index is also related to the position in a stem: in the wood it decreases, and in the bark it increases in the direction from the bottom up.
\end{abstract}

Key words: Scots pine, white birch, air pollution, copper smelter, model trees, sample plots, toxicity index, regression analysis.

\section{Introduction}

An integral indicator reflecting the natural and anthropogenic impact on forest ecosystems is their biological productivity. Assessment of biological productivity, or carbondepositing capacity of forests is now reaching the global level, and its increase is one of the main factors of climate stabilization, but "our understanding of changes in terrestrial biomass remains rudimentary" (Houghton et al., 2009).
This uncertainty is increasingly exacerbated by an air pollution factor. It is found that even a slight decrease in the biological productivity of forests under the influence of pollution has substantial negative impact on carbondepositing function of forest cover (Savva \& Berlinger, 2010), which reduces the "assimilation" resource forest cover and the opportunity to obtain benefits to the market of environmental services (Kozhukhova, 2001).

It is necessary to study the influence of atmospheric pollution on changes in the structure of biomass and net 
primary production (NPP) of forest ecosystems in gradients of industrial pollution. The lack of such information is one of the most important reasons that make it difficult to build an overall picture of the transformation of biota under the influence of industrial pollution (Zvereva \& Kozlov, 2012).

The vast expanses of the background environment of the Urals, combined with the presence of large long-term sources of air pollution, provide a unique opportunity to engage in experimental work with entire ecosystems at the level of territorial complexes. In the Urals one of the most intensive sources of toxic emissions is the copper production, in particular, the Karabash copper plant - KCP), Chely-

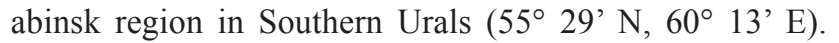
Because of the strong anthropogenic pollution on the territories plant nearest to KCSP, zonal ecosystems are completely destroyed: vegetation and soil humus are missing and an extensive technogenic wasteland is formed (Fig. 1).

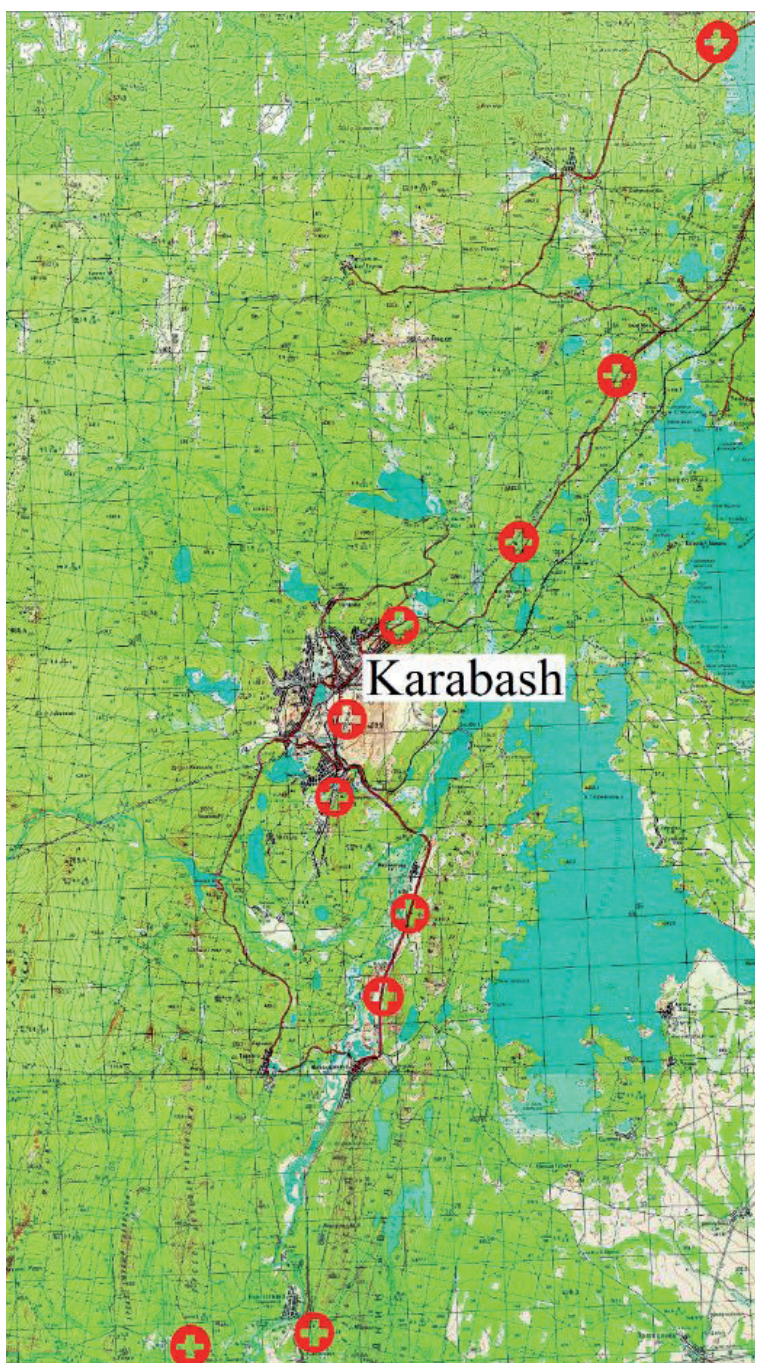

Figure 1. Locations of sample plot establishing in the northeast and south direction from KCP
Many publications describe vegetation reactions to technogenic pollution at the KCP polygon (Chernenkova et al., 1989; Stepanov et al., 1992; Chernenkova, 2002; Kozlov et al., 2009; Koroteeva et al., 2011; Kuyantseva et al., 2011). It was found that radial growth of pine is reduced by 2 times on the gradient of pollution at distances from 1 to $18 \mathrm{~km}$ in southern direction of the $\mathrm{KCP}$, while there is a violation of the growth correlation with climatic factors (Kucherov \& Muldashev, 2003). The radial growth also decreases as the sources of pollution are approached in white birch in the Central Urals (Makhnev et al., 1990), in Latvian Scots pine (Liepa et al., 1986) and in Siberian fir in Central Siberia (Pavlov, 2006).

As a result of studying the influence of atmospheric emissions of KCP on the apical growth, length and state of needles, the number of resin passages on the cross-section of needles of Scots pine, it was found that the apical growth depends on the amount of gross emissions of KCP. The most sensitive to air emission of KCP are the needle length in Scotch pine (Agikov, 2012), and the area of the leaf blade in white birch (Kuyantseva et al., 2011). The integral index of heavy metal content increases most significantly in leaves and to a lesser extent in bark and wood as birch trees approach the KCP (Koroteeva et al., 2015).

It is stated the increase of crown defoliation in Scots pine stands up to $50 \%$ as they approach the Krasnouralsky copper smelter (Vlasenko et al., 2001), the 4-5-fold increase of tree crown transparency as they approach pollution sources in different regions (Sidaravicius, 1987; Yarmishko, 1990; Brassel \& Schwyzer, 1992; Nizametdinov, 2009), but, at the same time, the density of needles on tree shoots is increasing (Augustaitis, 1989; Yarmishko, 1997; Zarubina, 2011). These two opposite trends overlap, and as a result, as we approach the source of pollution, there is no significant decrease in the biomass of trees, as was shown by the example of spruce and fir in the pollution gradient in the Central Urals (Usoltsev et al., 2011, 2012). However, at the stand level, all researchers of biomass structure of different species in pollution gradients came to an unambiguous conclusion about biomass decrease as it approaches the source of pollution (Lukina \& Nikonov, 1991; Stepanov et al., 1992; Yusupov et al., 1997; Chernenkova, 2002; Martynyuk, 2011; Usoltsev et al., 2012).

The purpose of this study is to establish patterns of changes in the structure of biomass and NPP of trees and stands of Scots pine and white birch in connection with an increase in the toxicity index in the pollution gradient at the Karabash copper smelter in the Southern Urals.

\section{Objects and methods}

The Karabash copper plant (KCP) has been operating since 1910. The main emission ingredients are sulfur dioxide 
( $91 \%$ by weight among gaseous pollutants) and dust particles with adsorbed toxic elements $(\mathrm{Cu}, \mathrm{Pb}, \mathrm{Zn}, \mathrm{Cd}, \mathrm{Fe}$, $\mathrm{Ni}$, etc.). The volume of emissions for the entire period of plant operation amounted to more than 15 million tons (Usoltsev et al., 2012).

The studies were carried out in two pollution gradients in predominantly pure birch and pine stands northeast of the KCP, and in birch stands also south of the plant (Fig. 1). 12 and 34 sample plots are established, in Scots pine (Table 1) and white birch (Table 2) stands respectively. The methods of work on the sample plots were described earlier (Usoltsev et al., 2011, 2012).

A total of 42 sample trees for pine and 56 ones for birch were taken. The number of disks sawn from the stems to determine the qualitative indices of wood and bark is following: 126 for pine and 168 for birch; the number of definitions of qualitative indices of the crown at the samples of foliage and branches (crown skeleton): 102 pine and 56 birch. To determine the biomass and NPP of regenera- tions and brushes, 169 and 515 sample trees of pine and birch are taken, respectively. Shares of the regenerations, brushes and grasses in the understory biomass and NPP in different pollution zones are shown in Table 3.

To estimate the stability of ecosystems, to predict their response to pollutants, to find the maximum permissible loads, it is necessary to build "dose - effect" relationships (Stepanov, 1988; Armand et al., 1991; Vorobeychik \& Khantemirova, 1994; Mikhailova \& Vorobeychik, 1995). It was revealed that the content of heavy metals in the humus layer of the soil changes in the pollution gradient at the KCP as it is removed from it, and this relationship has a nonlinear character (Koroteeva et al., 2015). Therefore, as an indicator of the "dose" we have adopted the toxicity index (index2), calculated from the concentration of mobile forms of the three most "manmade" metals $(\mathrm{Cu}, \mathrm{Pb}$ and $\mathrm{Fe})$ deposited in the forest litter, i.e. those metals that have the highest exceedances above the minimum level at the three dirtiest sites and the lowest

Table 1. Tree species composition* and taxation characteristics and harvest data** of stand aboveground biomass on 12 sample plots established in predominantly pure pine stands in the pollution gradient at the $\mathrm{KCP}$

\begin{tabular}{|c|c|c|c|c|c|c|c|c|c|c|c|c|c|c|c|c|c|c|}
\hline $\begin{array}{c}\text { Pollution } \\
\text { zone }\end{array}$ & $\begin{array}{c}D, \\
\mathbf{k m}\end{array}$ & $\begin{array}{c}\text { Species } \\
\text { composition }\end{array}$ & $A$ & $\boldsymbol{H}$ & $D B H$ & $N$ & $G$ & $V$ & Ps & $P b$ & $P f$ & $P a$ & $P u$ & $Z s$ & $Z b$ & $Z f$ & $Z a$ & $Z u$ \\
\hline \multirow{2}{*}{ Impact } & 4.2 & 7Ps3Bp & 80 & 20.6 & 26.9 & 392 & 15.97 & 179 & 84.1 & 11.9 & 3.65 & 99.6 & 0.12 & 1.05 & 0.446 & 1.30 & 2.82 & 0.112 \\
\hline & 5.5 & 9Ps1Bp & 80 & 19.9 & 31.1 & 422 & 27.97 & 323 & 154.2 & 22.2 & 6.97 & 182.2 & 0.33 & 1.94 & 0.774 & 1.66 & 4.4 & 0.312 \\
\hline \multirow{9}{*}{ Buffer } & 5.8 & 10Ps & 80 & 21.2 & 31.1 & 504 & 34.46 & 485 & 199,0 & 16.9 & 9.21 & 214.9 & 1.08 & 1.84 & 0.64 & 1.41 & 3.96 & 0.418 \\
\hline & 6.6 & $8 \mathrm{Ps} 1 \mathrm{Bp} 1 \mathrm{Pt}$ & 80 & 19.8 & 28.4 & 440 & 26.33 & 368 & 164.3 & 15.4 & 6.63 & 179.7 & 1.08 & 1.57 & 0.602 & 1.61 & 3.83 & 0.418 \\
\hline & 7.3 & $10 \mathrm{Ps}$ & 80 & 20.4 & 27.6 & 640 & 35.74 & 468 & 196,0 & 17,0 & 8.31 & 214.8 & 1.08 & 1.86 & 0.675 & 1.54 & 4.15 & 0.418 \\
\hline & 8.3 & 8Ps1Bp1Ls & 80 & 19.5 & 23.8 & 560 & 25.64 & 275 & 123,0 & 12.5 & 5.00 & 140.9 & 1.21 & 1.37 & 0.507 & 1.43 & 3.25 & 0.503 \\
\hline & 8.8 & 7Ps3Bp & 80 & 18.6 & 27.8 & 437 & 24.6 & 322 & 151.5 & 16.2 & 4.46 & 171.2 & 1.21 & 1.36 & 0.618 & 2.10 & 3.91 & 0.503 \\
\hline & 9.5 & 7Ps3Bp & 80 & 18.6 & 28.4 & 434 & 27.23 & 401 & 175.8 & 22.1 & 4.46 & 202.7 & 1.10 & 1.56 & 0.774 & 2.63 & 4.75 & 0.610 \\
\hline & 13.3 & $10 \mathrm{Ps}$ & 80 & 20.4 & 27.6 & 549 & 30.64 & 373 & 177.3 & 16.7 & 8.63 & 203.5 & 1.08 & 2.39 & 0.59 & 1.80 & 4.79 & 0.726 \\
\hline & 13.8 & $10 \mathrm{Ps}$ & 80 & 20.6 & 27.7 & 591 & 32.48 & 386 & 183.9 & 17.3 & 9.10 & 211.1 & 1.08 & 2.47 & 0.613 & 1.80 & 4.91 & 0.726 \\
\hline & 14.5 & 9Ps1Bp & 70 & 19.5 & 25.3 & 989 & 43.69 & 512 & 234.3 & 21.9 & 10.1 & 268.0 & 1.08 & 3.25 & 0.853 & 2.29 & 6.49 & 0.726 \\
\hline $\begin{array}{l}\text { Back- } \\
\text { ground }\end{array}$ & 32.0 & 8Ps2Bp & 80 & 20.3 & 28.5 & 600 & 35.0 & 492 & 196.7 & 17.6 & 6.70 & 219.8 & 1.25 & 2.98 & 0.85 & 2.21 & 5.97 & 0.573 \\
\hline
\end{tabular}

*Species designations: Ps - Pinus sylvestris L., Bp - Betula pendula Roth., Pt - Populus tremula L., Ls - Larix sibirica L.

** Stand designations: $D$ is distance from pollution source, $\mathrm{km} ; A$ is stand age, yrs; $H$ and $D B H$ are mean height and mean diameter at breast height correspondingly, in $\mathrm{m}$ and $\mathrm{cm} ; N$ is tree number per ha; $G$ is basal area, $\mathrm{m}^{2}$ per ha; $V$ is volume stock, $\mathrm{m}^{3}$ per ha; $P_{i}$ and $Z_{i}$ are biomass and annual NPP, t per ha; $i$ is the index of biomass component: stem with bark $(s)$, branches $(b)$, foliage $(f)$, aboveground $(a)$, and understory $(u)$. 


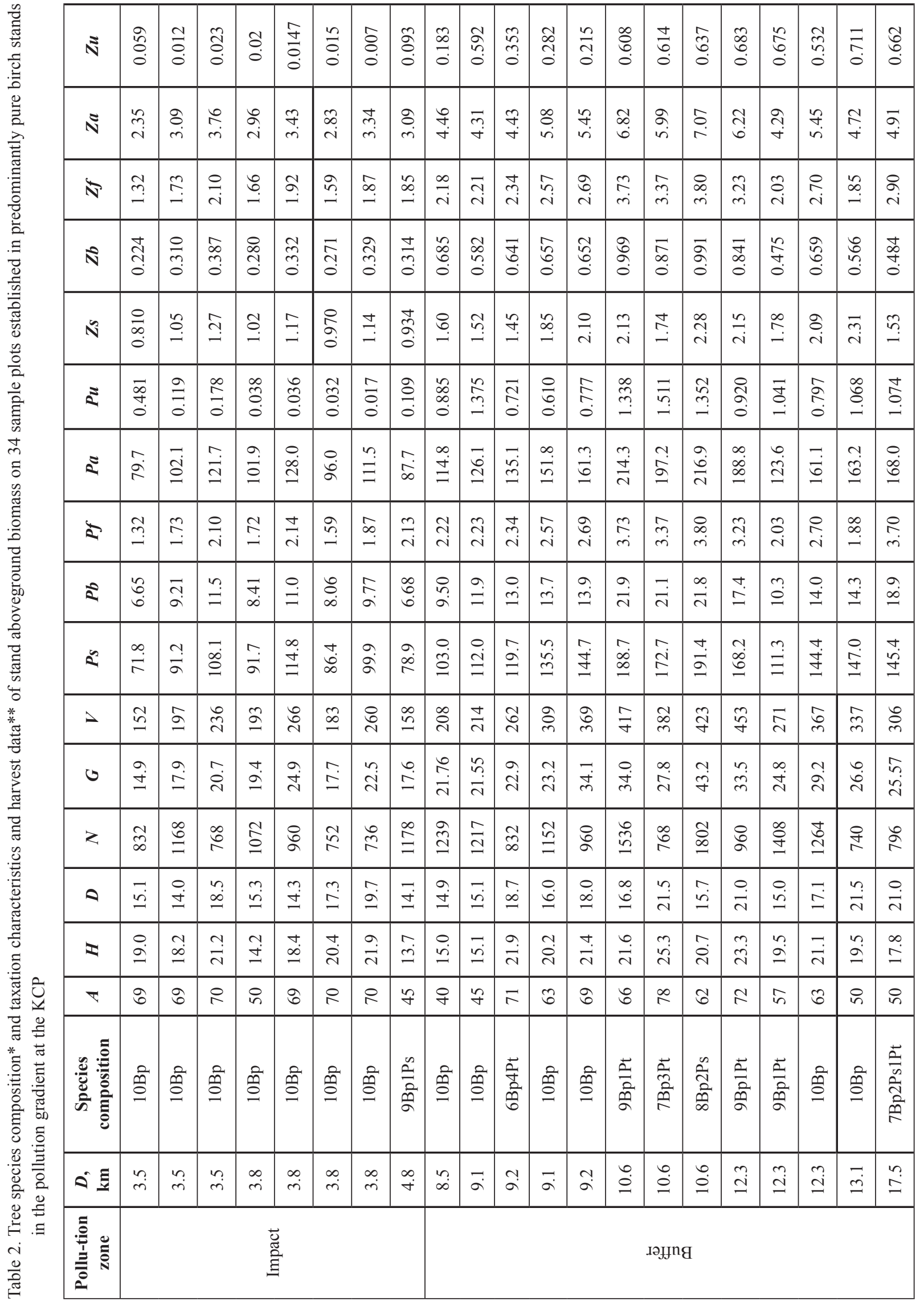




\begin{tabular}{|c|c|c|c|c|c|c|c|c|c|c|c|c|c|}
\hline ลี & $\begin{array}{l}8 \\
\infty \\
0 \\
0\end{array}$ & $\stackrel{\Xi}{\stackrel{\sigma}{\prime}}$ & $\stackrel{+}{5}$ & 苦 & $\frac{2}{\stackrel{2}{0}}$ & 今. & $\begin{array}{l}n \\
2 \\
0 \\
0 \\
0\end{array}$ & $\stackrel{t}{o}$ & $\vec{\sigma}$ & $\underset{\substack{N \\
0}}{\stackrel{0}{0}}$ & $\begin{array}{l}\hat{\sigma} \\
0 \\
0\end{array}$ & $\stackrel{\overbrace{}}{\stackrel{0}{0}}$ & 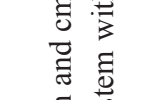 \\
\hline 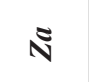 & $\underset{\infty}{\widehat{\infty}}$ & ते & $\begin{array}{l}n \\
\infty \\
\infty\end{array}$ & $\underset{\infty}{\infty}$ & $\begin{array}{l}\vec{\infty} \\
\infty\end{array}$ & $\underset{r}{\infty}$ & $\begin{array}{l}0 \\
\infty \\
\infty \\
\infty\end{array}$ & $\frac{m}{n}$ & $\stackrel{n}{i}$ & $\underset{\infty}{+}$ & & $\stackrel{?}{\circ}$ & 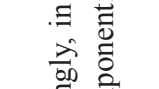 \\
\hline$\widehat{N}$ & 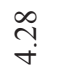 & $\stackrel{\vartheta}{r}$ & $\stackrel{n}{\stackrel{n}{+}}$ & $\begin{array}{l}\stackrel{0}{+} \\
\stackrel{+}{+}\end{array}$ & $\underset{\sim}{\tilde{r}}$ & $\begin{array}{l}n \\
\ddot{r} \\
\dot{r}\end{array}$ & $\underset{+}{\vec{f}}$ & $\stackrel{\stackrel{R}{i}}{i}$ & $\begin{array}{l}\infty \\
\infty \\
i\end{array}$ & $\stackrel{\substack{\sim \\
\sim}}{+}$ & $\underset{+}{\stackrel{f}{+}}$ & in & के \\
\hline ลี & $\stackrel{0}{=}$ & $\vec{\sigma}$ & $\stackrel{\text { ঙิ }}{-}$ & $\frac{\stackrel{2}{*}}{0}$ & 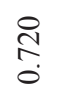 & 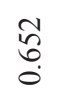 & $\stackrel{n}{\stackrel{2}{0}}$ & 岱 & $\hat{n}$ & 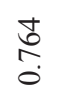 & ڤे & ô & 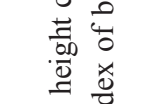 \\
\hline$\hat{v}$ & $\begin{array}{l}\mathscr{\infty} \\
\stackrel{i}{i}\end{array}$ & $\stackrel{\text { aे }}{i}$ & $\stackrel{\text { }}{\text { ì }}$ & $\bar{ल}$ & $\hat{\sigma}$ & $\hat{\mathrm{i}}$ & $\tilde{\sim}$ & $\hat{a}$ & $\stackrel{n}{a}$ & $\stackrel{q}{\stackrel{9}{n}}$ & 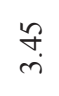 & $\stackrel{\infty}{\dot{m}}$ & 营 \\
\hline$\Xi$ & હે & 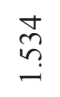 & 范 & $\underset{\Xi}{\Xi}$ & $\stackrel{\text { ָे }}{\cong}$ & $\stackrel{\infty}{\stackrel{\infty}{\longrightarrow}}$ & ڤั & $\stackrel{\&}{\leftrightarrows}$ & $\begin{array}{l}\infty \\
\stackrel{\infty}{+} \\
\rightarrow\end{array}$ & 范 & $\underset{\sim}{\stackrel{\infty}{\leftrightarrows}}$ & ָิ & 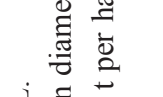 \\
\hline$\Xi$ & 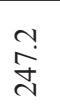 & $\overrightarrow{\vec{a}}$ & $\stackrel{m}{\stackrel{n}{N}}$ & $\begin{array}{l}\stackrel{\circ}{i} \\
\stackrel{\sim}{i}\end{array}$ & $\begin{array}{l}\stackrel{0}{\vec{\lambda}} \\
\stackrel{\text { an }}{ }\end{array}$ & ì & $\begin{array}{l}\text { हें } \\
\text { ते }\end{array}$ & $\begin{array}{l}n \\
\stackrel{2}{2} \\
n\end{array}$ & $\vec{g}$ & $\begin{array}{l}\dot{0} \\
\infty \\
\triangleq \\
\approx\end{array}$ & ث্. & $\begin{array}{l}0 \\
\infty \\
\infty \\
\infty \\
\sim\end{array}$ & 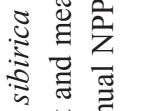 \\
\hline$\approx$ & $\stackrel{\substack{\mathcal{H} \\
\sim}}{ }$ & $\stackrel{\overbrace{}}{i}$ & $\stackrel{n}{\sim}$ & $\begin{array}{l}\stackrel{0}{+} \\
+\end{array}$ & $\underset{ָ}{+}$ & $\stackrel{n}{\mathscr{r}}$ & $\vec{\forall}$ & $\stackrel{\stackrel{R}{i}}{i}$ & $\begin{array}{l}\infty \\
\infty \\
i\end{array}$ & $\underset{\sim}{\stackrel{\infty}{\sim}}$ & $\underset{⿱}{\stackrel{*}{*}}$ & in & $\sqrt[7]{2}$ \\
\hline 2 & $\stackrel{\circ}{\circ}$ & 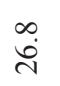 & $\overrightarrow{\vec{i}}$ & $\stackrel{\circ}{\infty}$ & $\stackrel{m}{\infty}$ & $\stackrel{n}{=}$ & $\stackrel{\circ}{\circ}$ & 亲 & $\vec{m}$ & $\begin{array}{l}n \\
\infty \\
\infty\end{array}$ & $\stackrel{n}{n}$ & $\ddot{n}$ & \\
\hline 2 & $\underset{\stackrel{i}{\sim}}{a}$ & $\begin{array}{l}n \\
\infty \\
\infty \\
\infty\end{array}$ & 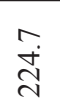 & $\begin{array}{l}\infty \\
\stackrel{\text { aे }}{\text { d }}\end{array}$ & 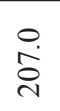 & $\underset{\sim}{\stackrel{\sim}{\sim}}$ & $\underset{\sim}{\stackrel{\sim}{\sim}}$ & aे & $\ddot{n}$ & $\stackrel{\vec{n}}{\vec{\sim}}$ & $\begin{array}{l}\text { तु. } \\
\text { तై }\end{array}$ & ڤें & $\underset{\Xi}{J}$ \\
\hline$\lambda$ & $\tilde{n}$ & $\stackrel{q}{q}$ & $\stackrel{\infty}{\stackrel{\infty}{\sigma}}$ & $\hat{\tilde{n}}$ & $\underset{\infty}{\infty}$ & $\stackrel{\leftrightarrow}{q}$ & $\tilde{n}$ & $\frac{\infty}{m}$ & $\hat{\bar{े}}$ & 号 & $\tilde{n}$ & $\tilde{\delta}$ & \\
\hline ن & $\stackrel{\infty}{\stackrel{\infty}{m}}$ & ?̊ & $\hat{\dot{\delta}}$ & $\vec{m}$ & $\hat{\dot{m}}$ & $\frac{m}{m}$ & $\begin{array}{l}\infty \\
\stackrel{m}{m}\end{array}$ & $\stackrel{\circ}{\stackrel{+}{\sim}}$ & 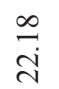 & $\frac{\sigma}{m}$ & ஸ̃ & ণ্ं & \\
\hline$z$ & $\frac{\pi}{\sigma}$ & तิ & $\begin{array}{c}\infty \\
\infty \\
\infty\end{array}$ & $\stackrel{\infty}{\varrho}$ & $\approx$ & $\frac{\pi}{\sigma}$ & \& & $\tilde{\infty}$ & $\stackrel{\infty}{\infty}$ & $\underset{\sigma}{\sigma}$ & ू̆ & 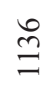 & \\
\hline$\theta$ & $\underset{\text { ì }}{\text { in }}$ & तై & $\tilde{\sim}$ & $\stackrel{\circ}{9}$ & 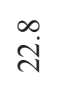 & 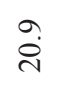 & $\stackrel{n}{\grave{v}}$ & $\stackrel{\sim}{\sim}$ & $\stackrel{9}{\Xi}$ & $\overline{\vec{N}}$ & $\stackrel{m}{\sim}$ & $\stackrel{\circ}{\stackrel{i}{N}}$ & ఏ్ర \\
\hline$\approx$ & $\stackrel{\leftrightarrow}{\dot{\sim}}$ & $\begin{array}{l}0 \\
\ddot{i}\end{array}$ & $\begin{array}{l}\infty \\
\text { aे }\end{array}$ & 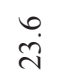 & 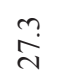 & $\ddot{n}$ & $\overrightarrow{\dot{D}}$ & $\begin{array}{l}\infty \\
\underset{\sim}{(j}\end{array}$ & $\stackrel{\circ}{-}$ & $\begin{array}{l}\dot{0} \\
\ddot{d}\end{array}$ & 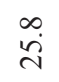 & $\begin{array}{l}\dot{0} \\
\ddot{d}\end{array}$ & \\
\hline$\nabla$ & 8 & $\nabla$ & $\mathbb{2}$ & $\infty$ & $\stackrel{\nabla}{\sim}$ & $\nabla$ & $\mathbb{N}$ & $\infty$ & 웅 & $\mathbb{N}$ & $\mathbb{N}$ & $\mathbb{R}$ & \\
\hline 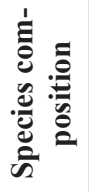 & 今े & 옹 & о응 & 옹 & ळิ & $\begin{array}{l}\text { 品 } \\
\text { مै }\end{array}$ & $\begin{array}{l}\hat{n} \\
\overrightarrow{\tilde{n}} \\
\tilde{a}\end{array}$ & 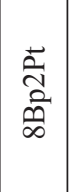 & 各 & 용 & оิ & 今ิ & 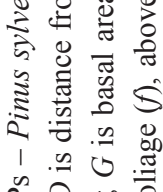 \\
\hline Q & $\begin{array}{l}n \\
\infty \\
\infty\end{array}$ & $\underset{\infty}{n}$ & $\begin{array}{l}n \\
\infty \\
\infty \\
\infty\end{array}$ & तें & $\begin{array}{l}\infty \\
\dot{n} \\
\dot{v}\end{array}$ & $\stackrel{\vec{\infty}}{\stackrel{N}{N}}$ & $\begin{array}{c}\hat{\infty} \\
\dot{\sim} \\
\dot{\sim}\end{array}$ & $\hat{\sim}$ & $\stackrel{\circ}{m}$ & $\stackrel{i}{m}$ & $\frac{r}{m}$ & $\stackrel{i}{m}$ & 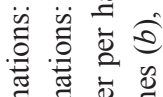 \\
\hline 彦 & & 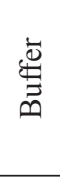 & & & & & 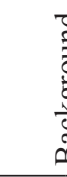 & & & & & & 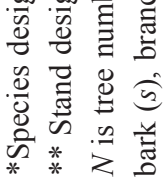 \\
\hline
\end{tabular}


Table 3. Shares of the regenerations, brushes and grasses in the understory biomass and NPP in different pollution zones

\begin{tabular}{|c|c|c|c|c|c|c|c|c|}
\hline \multirow{2}{*}{ Pollution zone } & \multicolumn{4}{|c|}{ Biomass, \% } & \multicolumn{4}{|c|}{ NPP, \% } \\
\hline & Regenera-tion & Brush & Grass & Total & Regeneration & Brush & Grass & Total \\
\hline \multicolumn{9}{|c|}{ Pine stands } \\
\hline Impact & 4 & 2 & 94 & 100 & 0.5 & 0.2 & 99.3 & 100 \\
\hline Buffer & 22 & 34 & 44 & 100 & 4 & 6 & 90 & 100 \\
\hline Background & 16 & 43 & 41 & 100 & 3 & 7 & 90 & 100 \\
\hline \multicolumn{9}{|c|}{ Birch stands } \\
\hline Impact & 32 & 48 & 20 & 100 & 15 & 22 & 63 & 100 \\
\hline Buffer & 20 & 34 & 46 & 100 & 4 & 6 & 90 & 100 \\
\hline Background & 19 & 24 & 57 & 100 & 3 & 3 & 94 & 100 \\
\hline
\end{tabular}

exceedances at the three sites furthest from the emission source. In contrast to sulfur, they are stronger adsorbed by depositing environments, and they are easier to measure on polygons of a large area (Mikhailova \& Vorobeichik, 1995).

In this case, index 2 is calculated for concentrations of mobile forms of $\mathrm{Cu}, \mathrm{Pb}$ and $\mathrm{Fe}$ in forest litter according to the following formula

$$
\text { index2 }=\frac{1}{k} * \Sigma \frac{X_{i j}}{X_{i m i n}}
$$

where, $k$ is a number of elements (in our case - three); $X i j$ is concentration of $i$-th element on $j$-th site; $X_{i \text { min }}$ is minimum concentration of $i$-th element on all sites.

\section{Results and discussion}

To assess the impact of pollution on the structure of tree biomass, the allometric equations are calculated, having the form

$$
p_{i}=\exp \left[\mathrm{a}_{0}+\mathrm{a}_{1} \ln (\mathrm{DBH})+\mathrm{a}_{2}(X)+\mathrm{a}_{3} \ln (I)\right]
$$

where $p_{i}$ is biomass of $i$-th component, $\mathrm{kg}$; DBH is stem diameter at breast height, $\mathrm{cm}$; $I$ is toxicity index (index2); $X$ - binary variable, equal 1 for pine and 0 for birch. The calculation of (2) for aboveground biomass, stems, foliage and branches, showed the following coefficients of determination, correspondingly: $0.981,0.972,0.861$ and 0.951 . The significance level according to the Student's criterion for the constant $\mathrm{a}_{2}$ was 10.6, 9.9, 12.1 and 18.1 respec- tively. This means that the difference of allometric dependences of biomass components upon DBH in pine and birch is highly reliable (at the level of probability $\mathrm{P}_{999}$ ).

But for the constant $\mathrm{a}_{3}$ the significance level was 1.1, $0.9,1.1$ and 0.4 respectively, which is significantly less than the critical value $t_{05}=2$. This means that the biomass structure of equal-sized trees of both species remains unchanged throughout the pollution gradient. As it was mentioned above, this phenomenon may be explained with joining two contrary trends, i.e. firstly, increasing foliage density on twigs and, secondly, increasing crown transparency when approaching pollution source. Thus, these two contrary trends overlap and the total trend is absent.

This also means that ignoring of previously obtained experimental data of tree biomass and seeking new experimental data to calculate "modern" allometric equations, supposedly more appropriate to the changed environmental conditions (Xing et al., 2005), is completely unfounded.

Similar equations are calculated for the annual growth of tree biomass. The obtained equations for each sample plot are further used to calculate biomass and NPP per 1 ha, which are then analyzed in relation to the toxicity index.

A standard regression analysis procedure was used to approximate "dose - effect" relationships. The dependencies were analyzed

$$
\begin{aligned}
& P_{i}=\exp \left[\mathrm{a}_{0}+\mathrm{a}_{1} \ln I+\mathrm{a}_{2}(X \times \ln I)\right], \\
& Z_{i}=\exp \left[\mathrm{a}_{0}+\mathrm{a}_{1} \ln I+\mathrm{a}_{2}(X \times \ln I)\right] .
\end{aligned}
$$

Designations in (3) and (4) see in Table 1. All regression coefficients of the independent variables of the calculated equations are significant at the probability level 
of 0.95 and above. When calculating equations (3) and (4), the taxation characteristics of pine and birch stands were consistently included as additional independent variables. However, in most cases their influence on biomass and NPP of forest stands in the pollution gradient was not statistically reliable. The characteristics of the final equations is given in Table 4 and their graphical interpretation in Figure 2.

If no significant impact on the aboveground biomass and its annual NPP of pine and birch in the gradient of pollution from KCP was revealed at a tree level, at a stand level such an impact was significant. This means that the change in biological productivity of stands in the pollution gradient is influenced not by the structure of biomass and NPP of their constituent trees, but by the taxation structure of stands.

A previously published paper (Usoltsev et al., 2012) the dependence of biomass and NPP of trees and stands was investigated in the same pollution gradient on the $\mathrm{KCP}$, but the pollution index was the distance from the source of pollution. The first output was like this: if an influence of pollution from KCP on aboveground biomass and annual NPP of pine and birch trees in the gradient was no significant, their influence at a forest stand level is obvious.

However, there are differences concerning the traits of the studied dependencies. Judging by the structure of equations (3) and (4), shown in Table 5, and their graphical interpretation (Fig. 2), the obtained dependences of the stands production indices on the toxicity index are described by a simple allometric function, whereas their relation to the distance from the pollution source $(D, \mathrm{~km})$ was described by the equation

$$
P_{i} \text { and } Z_{i}=\mathrm{a}_{0}+\mathrm{a}_{1}(1 / D)^{2},
$$

according to which, after the sharp increase in $P_{i}$ and $Z_{i}$ in the range of distances from 4 to $10 \mathrm{~km}$, as they move away from the KCP, they gradually stabilize with the exit to the plateau.

Since in determining the biological productivity of stands in the sample plots, the main share of labor is spent on determining the dry matter content (DMC) in biomass components, we estimated dependences of DMC in biomass components upon determining factors that could be useful in studies of this nature at similar facilities. The equations for DMC are calculated:

- in stem components

$$
S w \text { and } S b=\mathrm{a}_{0}+\mathrm{a}_{1} I+\mathrm{a}_{2} X+\mathrm{a}_{3} h
$$

- and in foliage and branches

$$
S f \text { and } S b r=\mathrm{a}_{0}+\mathrm{a}_{1} I+\mathrm{a}_{2} X,
$$

where $S w, S b, S f$ and $S b r$ are dry matter content in stem wood and bark, in foliage and branches, respectively, $\% ; h-$ position of sawn disks along the stem, in shares of the stem height, i.e. $0.2,0.5$ and $0.8 H$ (numbering from bottom to top), where $H$ is the stem height, $\mathrm{m} ; I-$ index toxicity (Index 2); $X$ is a binary variable equal to 1 for pine and 0 for birch. All regression coefficients of the independent variables of the calculated equations (6) and (7) are significant at the probability level of 0.95 and above. The characteristic of equations (6) and (7) is given in Table 6.

When judging by the characteristic of equations (6) and (7), the dry matter content in the stem wood decreases and in the bark increases from the bottom up; due to the increase in the toxicity index, DMC in the wood and bark decreases, and in the foliage and branches increases. At the same toxicity index, DMC in the stem wood and branches is more in birch, and in bark and foliage is more in pine.

For preliminary (approximate) calculations or in cases where it is not possible to determine the DMC in the biomass components by the thermal-weight method when

Table 4. Characteristic of equations (3) and (4) for pine and birch stands in the pollution gradient near the KCP

\begin{tabular}{|c|c|c|c|c|c|c|c|c|c|c|}
\hline $\begin{array}{c}\text { Equation } \\
\text { characteristic }\end{array}$ & $\boldsymbol{P a}$ & $\boldsymbol{P s}$ & $\boldsymbol{P f}$ & $\boldsymbol{P b}$ & $\boldsymbol{P u}$ & $\boldsymbol{Z a}$ & $\boldsymbol{Z s}$ & $\boldsymbol{Z f}$ & $\boldsymbol{Z b}$ & $\boldsymbol{Z u}$ \\
\hline $\mathrm{a}_{0}$ & 5.4703 & 5.3530 & 1.5307 & 3.0375 & 0.8666 & 2.0606 & 1.1305 & 1.3444 & -0.1412 & 0.4393 \\
\hline $\mathrm{a}_{1}$ & -0.1755 & -0.1744 & -0.2072 & -0.1701 & -0.6590 & -0.1888 & -0.2281 & -0.1593 & -0.1882 & -0.8222 \\
\hline $\mathrm{a}_{2}$ & 0.1026 & 0.1000 & 0.2932 & 0.1125 & 0.3514 & 0.0165 & 0.0733 & -0.0575 & 0.1058 & 0.4650 \\
\hline$a d j \mathrm{R}^{2}$ & 0.594 & 0.587 & 0.697 & 0.465 & 0.671 & 0.672 & 0.708 & 0.621 & 0.483 & 0.804 \\
\hline $\mathrm{SE}$ & 1.24 & 1.24 & 1.33 & 1.31 & 1.98 & 1.24 & 1.25 & 1.28 & 1.33 & 1.83 \\
\hline
\end{tabular}

Designations of symbols: $P_{i}$ and $Z_{i}$ are biomass and annual NPP, t per ha; $i$ is the index of biomass component: aboveground ( $a$ ), stem with bark $(s)$, foliage $(f)$, branches $(b)$, and understory $(u)$. 

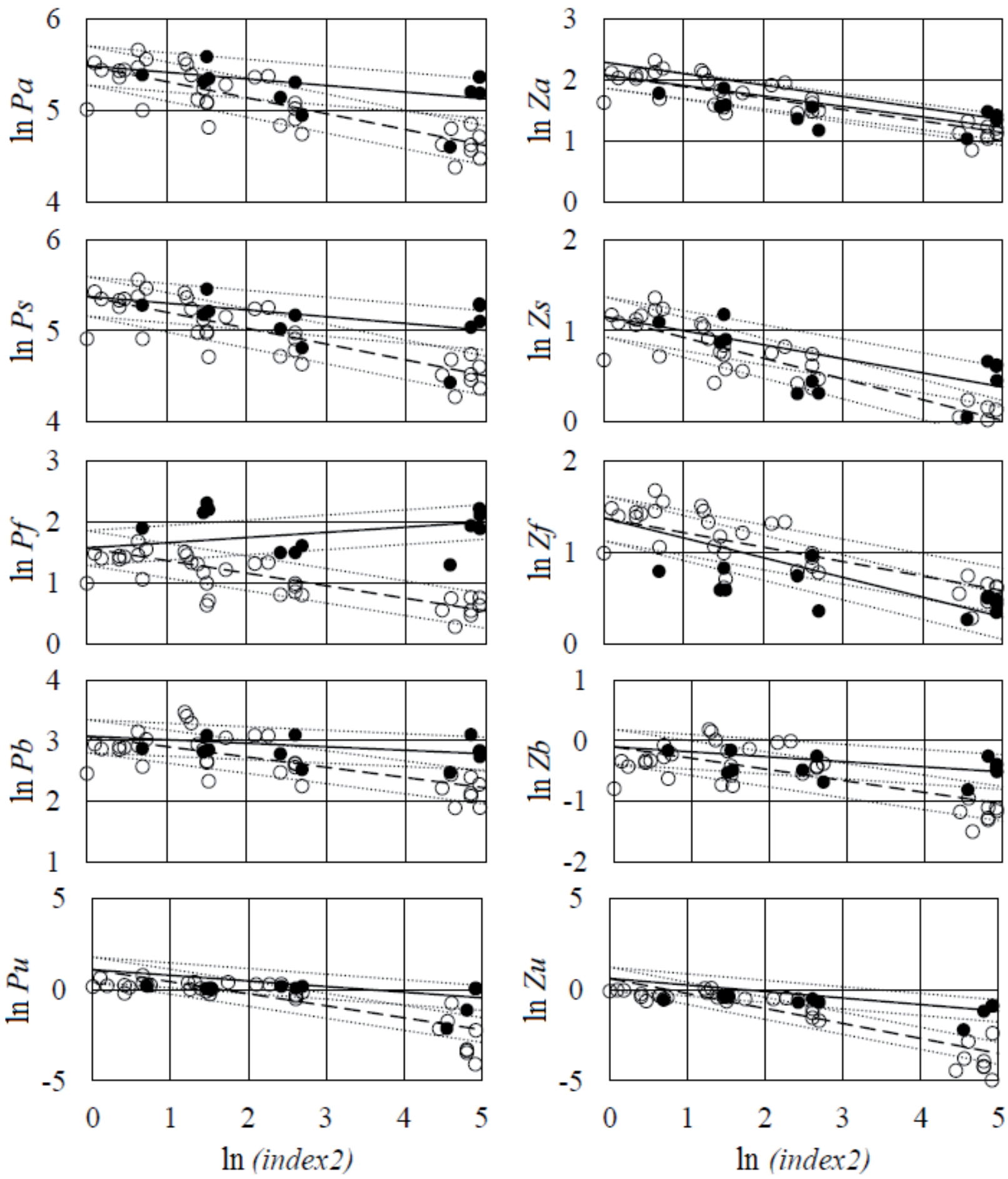

\section{Scots pine}

- - - White birch

Figure 2. Linear log-log change trends of biomass (left) and annual NPP (right) of pine and birch stands in the pollution gradient at KCP. The dotted lines show the range of the standard error of the equations 
Table 6. The characteristic of equations (6) and (7)

\begin{tabular}{|c|c|c|c|c|}
\hline Equation characteristics & $\boldsymbol{S w}$ & $\boldsymbol{S b}$ & $\boldsymbol{S f}$ & \multicolumn{1}{c|}{$\boldsymbol{S b r}$} \\
\hline $\mathrm{a}_{0}$ & 67.13 & 32.58 & 37.86 & 52.69 \\
\hline $\mathrm{a}_{1}$ & -0.024 & -0.022 & 0.011 & -6.155 \\
\hline $\mathrm{a}_{2}$ & -4.39 & 19.35 & 9.26 & - \\
\hline $\mathrm{a}_{3}$ & -18.31 & 6.93 & - & 0.638 \\
\hline$a d j \mathrm{R}^{2}$ & 0.636 & 0.797 & 0.835 & 2.22 \\
\hline $\mathrm{SE}$ & 3.86 & 4.88 & 2.00 & 2.2 \\
\hline
\end{tabular}

Table 7. Average DMC ( \% ) in pine and birch biomass components in the pollution gradient at KCP

\begin{tabular}{|c|c|c|}
\hline Biomass component & Pine & Birch \\
\hline Stem wood & $52.5 \pm 0.60$ & $35.4 \pm 0.44$ \\
\hline Stem bark & $54.1 \pm 0.70$ & $53.1 \pm 0.21$ \\
\hline Branches with their bark & $47.0 \pm 0.23$ & $38.4 \pm 0.20$ \\
\hline Foliage & $47.6 \pm 0.29$ & \\
\hline
\end{tabular}

evaluating it on sample plots in the stands of pine and birch, its average values can be used (Table 7).

\section{Conclusion}

Thus, it is not revealed any statistically significant patterns of change in biomass and annual NPP of trees in the gradient of the index of toxicity, but at the stand level, a linear log-log pattern of declining biomass and annual NPP of forest stands with increasing index of toxicity in the direction to the source of pollution have been established, and most of the components reduce in birch more pronounced than in pine. The exception is the ratio of these trends in pine and birch related to biomass and NPP foliage.

Neither the age of a tree nor its size contribute significantly to the explanation of the variability of DMC in biomass components. But DMC of all the components of biomass depends upon the value of the toxicity index and species on a statistically significant level: due to the increase in the toxicity index, DMC in wood and bark decreases, and in foliage and branches increases. At the same toxicity index DMC in the stem wood and branches above birch, and in the bark and foliage above pine. In the stem wood and bark, this indicator is also related to the position in a stem: in the wood it decreases, and in the bark it increases in the direction from the bottom up.
The use of the toxicity index in the pollution gradient enables a comparative analysis of pollution situations at different sites and some physiologically determined interpretations of the revealed trends.

\section{Acknowledgement}

The authors thank their colleagues E.L. Vorobeichik, I.E. Bergman, M.R. Trubina, S.Y. Kaygorodova, P.G. Pishchulin, A.V. Sapelkin and I. Biktimirov involved in obtaining raw materials and I.S. Tsepordey preparing the manuscript for publication.

\section{References}

Agikov I.N., 2012, The influence of non-ferrous smelt atmospheric emissions on Scots pine (Pinus sylvestris L.) forests (South Urals). Vestnik Udmurtskogo Universiteta 2: 24-30 [in Russian].

Armand A.D., Kaydakova V.V., Kushnareva G.V. \& Dobrodeev V.G., 1991, Determination of the limits of geosystems' stability on the example of the vicinity of the Monchegorsk metallurgical works. Izv. Akad. Nauk SSSR, Ser. Geografich. 1: 93-104 [in Russian].

Augustaitis A.A., 1989, Features of formation of aboveground phytomass of pine young forests in conditions 
of pollution of the environment, [in:] Problems of ecological monitoring and modeling of ecosystems. Vol. 12. Gidrometeoizdat, Leningrad: 32-51 [in Russian].

Brassel P. \& Schwyzer A., 1992, Ergebnisse der Waldschadeninventur 1992, [in:] Sanasilva - Waldschadenbericht 1992. WSL, Bern und Birmensdorf: 7-18.

Chernenkova T.V., 2002, Reaction of forest vegetation to industrial pollution. "Nauka", Moscow, 190 pp. [in Russian].

Chernenkova T.V., Stepanov A.M. \& Gordeeva M..M., 1989 , Changes in the organization of forest phytocenoses in technogenesis. Zhurnal Obshchei Biologii 3: 388-394 [in Russian].

Houghton R.A., Hall F. \& Goetz S.J., 2009, Importance of biomass in the global carbon cycle. Journal of Geophysical Research 114: 1-13 (G00E03, doi:10.1029/2009JG000935).

Koroteeva E.V., Veselkin D.V., Kuyantseva N.B., Mumber A.G. \& Chashchina O.E., 2015, Accumulation of heavy metals in the different Betula pendula Roth organs near the Karabash Copper Smelter. Agrokhimiya (Agrochemie) 3: 88-96 [in Russian].

Koroteeva E.V., Veysberg E.I. \& Kuyantseva N.B., 2011, Assessment of forest cenoflora in the impact zone of the Karabash Copper Smelter (Southern Urals). Izv. Samar. Sci. Center of RAS 13(1): 1005-1011 [in Russian].

Kozhukhova L.I., 2001, Assimilative resource of Russia and its place among the priorities of national forest policy, [in:] National forest policy of Russia / Proc. of the intern. scient.-practical conf. MGUL, Moscow: 154-156 [in Russian].

Kozlov M.V., Zvereva E.L. \& Zverev V.E., 2009, Impacts of point polluters on terrestrial biota: Comparative analysis of 18 contaminated areas. Springer, Dordrecht, $466 \mathrm{pp}$

Kucherov S.E. \& Muldashev A.A., 2003, Radial increment of Scotch pine in the vicinity of the Karabash Copper Smelter. Lesovedenie 2: 43-49 [in Russian].

Kuyantseva N.B., Mumber A.G., Potapkin A.B. \& Gavrilkina S.V., 2011, Reaction of birch stands to acid emissions generated by the Karabash Copper Smelter (Southern Urals). Bulletin of the Orenburg State University 12(131): 98-100 [in Russian].

Liepa I.Ya., Nicodemus O.E., Raman K.K. \& Skudra A.Ya., 1986, Time course of pine forests reaction in conditions of changeable air pollution, [in:] Temporal aspects of modeling and forecasting in ecology. Collection of scientific papers. Latvian State University, Riga: 114-127 [in Russian].

Lukina N.V. \& Nikonov V.V., 1991, Changes in the primary productivity of spruce stands under the influence of man-made pollution in the Kola North. Lesovedenie 4: 37-45 [in Russian].
Makhnev A.K., Trubina M.R. \& Paramonov S.A., 1990, Forest vegetation in the vicinity of non-ferrous metallurgy, [in:] Natural vegetation of industrial and urbanized territories of the Urals. Ural Branch of Academy of Sci. USSR, Sverdlovsk: 3-41 [in Russian].

Martinyuk A.A., 2011, Peculiarities of formation of surface phytomass in young pine stands affected by industrial pollution. Lisoviy Zhurnal 2: 13-18 [in Russian].

Mikhailova I.N. \& Vorobeichik E.L., 1995, Epiphytic lichenosynusia under conditions of chemical pollution: dose-effect dependencies. Russian Journal of Ecology 26(6): 425-431.

Nizametdinov N.F., 2009, Assessment of the state of pine stands in the conditions of agro-industrial pollution of the atmosphere by digital photographs of tree crowns and satellite photographs. Abstract PhD. USFEU, Yekaterinburg, 19 pp. [in Russian].

Pavlov I.N., 2006, Woody plants in conditions of technogenic pollution. Buryatia Publishing House, Ulan-Ude, 360 pp. [in Russian].

Savva Y. \& Berlinger F., 2010, Sulphur deposition causes a large-scale growth decline in boreal forests in Eurasia. Global Biogeochemical Cycles 24 (GB3002, doi:10.1029/2009GB003749).

Sidaravicius I.M., 1987, Analysis of phytomass and morphological structure of crowns of a pine forest under atmospheric pollution, [in:] Research and simulation of growth of forests growing in the polluted natural environment. Collect. of scientific. papers. Lituanian Agrarian Academy, Kaunas: 45-55 [in Russian].

Stepanov A. M., 1988, Methodology of. bioindication and background monitoring of terrestrial ecosystems, [in:] Ecotoxicology and Environmental Protection. Moscow: 28-108 [in Russian].

Stepanov A.M., Kabirov R.R., Chernenkova T.V., Sadykov O.F., Khanislamov G.M., Nekrasova L.S., Butusov O.B. \& Balcewicz L.A., 1992, Integrated environmental assessment of anthropogenic impact on ecosystems of southern taiga / A. M. Stepanov (ed.). Promekologia, Moscow, 246 pp. [in Russian].

Usoltsev V.A., Vorobeichik E.L. \& Bergman I.E., 2012, Biological productivity of Ural forests under conditions of air pollutions: studying a system of regularities. Ural State Forest Engineering University, Yekaterinburg, 366 pp. [in Russian]. (http://elar.usfeu.ru/ handle/123456789/458).

Usoltsev V.A., Vorobeichik E.L., Bornikov A.V. \& Zhanabayeva A.S., 2011, Biological productivity of forests near the Ural copper smelters // Boreal Forests in a Changing World: Challenges and Needs for Actions. Proceedings of 15th IBFRA International Science Conference, August 15-21 2011. V.N. Sukachev Institute of Forest SB RAS, Krasnoyarsk: 193-197. 
(http://ibfra.org/documents/IBFRA_proceedings_2011. pdf).

Vlasenko V.E., Menshchikov S.L. \& Andreev G.V., 2001, To the question of studying the productivity of pine forests in the conditions of regional industrial pollution. Forest Taxation and Forest Management 1: 145-147 [in Russian].

Vorobeichik E.L. \& Khantemirova E.V., 1994, Reaction of forest phytocenoses to technogenic pollution: Doseeffect dependencies. Russian Journal of Ecology 25(3): 171-180.

Xing Z., Bourque C.P.-A., Swift D.E., Clowater C.W., Krasowski M. \& Meng F.-R., 2005, Carbon and biomass partitioning in balsam fir (Abies balsamea). Tree Physiology 25: 1207-1217.

Yarmishko V.T., 1990, State of pine assimilation apparatus, [in:] Influence of industrial atmospheric pollution on pine forests of the Kola Peninsula. V.L. Komarov Botanical Institute, Leningrad: 55-64 [in Russian].
Yarmishko V.T., 1997 Scots pine and atmospheric pollution in the European North. Research Institute of Chemistry, St-Peterburg, 210 pp. [in Russian].

Yusupov I.A., Zalesov S.V. \& Luganskiy N.A., 1997, Aboveground phytomass of artificial young pine forests in the conditions of air emissions in the Middle Urals, [in:] Biological reclamation of disturbed lands. Institute of Forest, Ural Branch of RAS, Yekaterinburg: 266-278 [in Russian].

Zarubina I.A., 2011, Assessment of the state of Scots pine (Pinus sylvestris L.) plantations under conditions of air pollution (Ust-Ilim district, Irkutsk region). PhD Abstract. SibGTU, Krasnoyarsk, 17 pp. [in Russian].

Zvereva E.L. \& Kozlov M.V., 2012, Changes in the abundance of vascular plants under the impact of industrial air pollution: A meta-analysis. Water Air and Soil Pollution 223(5): 2589-2599. (DOI: 10.1007/s11270-011$1050-\mathrm{z})$. 